\title{
What Does it Mean to Orient Oneself in Thinking?
}

Was heißt: sich im Denken orientieren?

October 1786

Königsberg in Prussia, Germany.

By

\section{Immanuel Kant}

(Born in 1724 and died in 1804)

Translation into English by Daniel Fidel Ferrer (March, 2014)

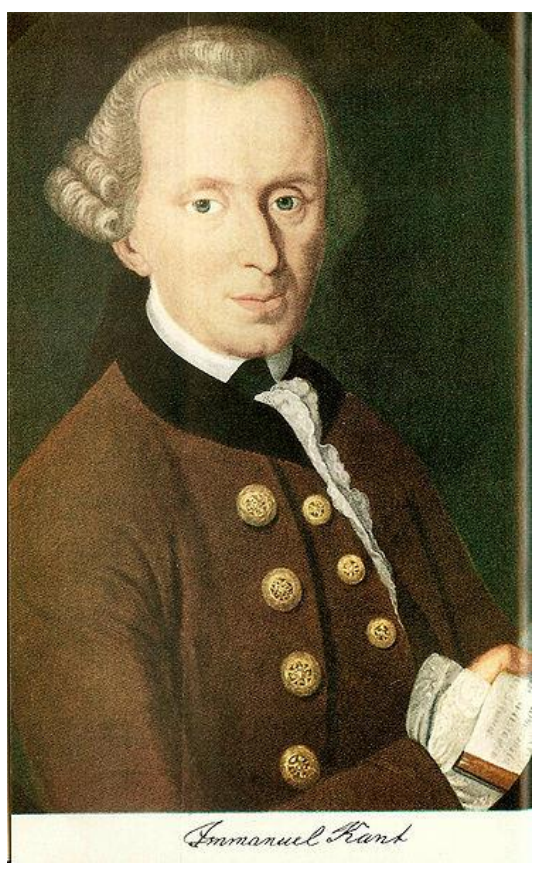


What Does it Mean to Orient Oneself in Thinking? / By Immanuel Kant (1724-1804).

[Was heißt: sich im Denken orientieren? English].

Translation of text, notes, essays, chronology, etc by

Copyright (92014 Daniel Fidel Ferrer.

All rights reserved. Free unlimited distribution.

Creative Commons General Public License "Attribution, Non-Commercial", version 3.0 (CCPL BY-NC).

\section{Table of Contents}

Translator's Short Preface for Historical Context (pages 3-4).

Immanuel Kant's Text translated into English (pages 5-22).

Translator's Remarks (pages 23-24).

Notes and Background for Kant's essay and translation (page 25).

Earlier translations from German into English of Kant's essay (page 26).

Pantheism Controversy (Quarrel) (Pantheismusstreit) (pages 27-28).

Chronology of the Pantheism Controversy (Quarrel) (pages 29-37).

Main Philosophers and authors. Ranked by birth year.

Lessing first quarrel. Fragments Controversy.

Pantheism Controversy or Pantheism Quarrel starts.

Atheism Controversy.

What is the Purpose of Kant's Orientation Essay? (pages 38-42).

Selected Bibliography related to Pantheism Controversy (pages 42-43).

Related Online Resources (pages 43-44).

Kant's Note on his Overall Philosophical Position (pages 45-47).

Dedication and Acknowledgements (pages 48-49).

Appendix A. Image of first page of Kant Essay (1786) (pages 49-51).

Keyword index (pages 51-83). Starts with a green page. 


\section{Translator's Short Preface for the Historical Context}

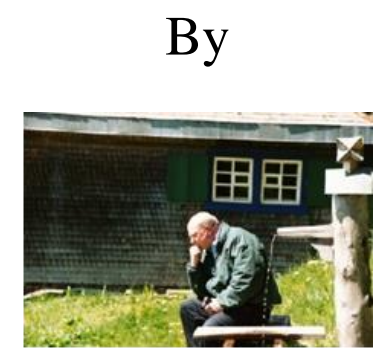

\section{Daniel Fidel Ferrer}

From 1774 to about 1800, there were three intense philosophical and theological controversies underway in Germany, namely: Fragments Controversy, the Pantheism Controversy, and the Atheism Controversy. Kant's essay translated here is Kant's respond to the Pantheism Controversy. During this period (1770-1800), there was the Sturm und Drang (Storm and Urge (stress)) movement with thinkers like Johann Hamann, Johann Herder, Friedrich Schiller, and Johann Goethe; who were against the cultural movement of the Enlightenment (Aufklärung). Kant was on the side of Enlightenment (see his Answer the Question: What is Enlightenment? 1784). Kant's essay here is problematic, challenging in German, and certainly not easy to translate into English. Remember: this is the way Kant wrote this essay; and if you can improve on his writing, I strongly suggest you go ahead. If you are looking for a summary of Kant's essay, look elsewhere. Indeed, there are earlier translations that have rewritten Kant and make more sense in English than this translation (see page 26). I did not re-write or "fix" Kant's essay. This translation is closer to Kant's actually wording. I have added a lengthy chronology to give a better historical context of the three controversies (see pages 29-37). The question of the main purpose of Kant's essays (see my interpretation on pages $38-42$ ).

Where does Kant's critical philosophy fit between rationalism and faith, between deism and theism, between some versions of skepticism and 
common sense? Whom should we consider as the guiding light of philosophy: Spinoza or Leibniz? Were the Leibnizians crypto-Spinozists? Alternatively, should it be the promotion of Kant's critical philosophy? Spinoza was considered an atheist at the time. Accordingly, Spinoza was considered to believe in pantheism, atheism, nihilism, fatalism, and no personal God. Direct path: metaphysics leads to pantheism, pantheism is really Spinozism, Spinozism is fatalism, and fatalism is in fact, and finally: just simply, Spinozism $\underline{i}$ atheism. Potentially all philosophy and all metaphysics, therefore, leads to atheism too. These fears were whipped up against all philosophers of the time. Kant was of course - contra atheism.

F. H. Jacobi's position was faith and revelation was the central source for our theological and philosophical orientation. What should be our philosophical, theological, and metaphysical 'orientation' in the middle of these controversial philosophical worldviews and positions? Which direction should we go philosophically? Should these theology views dedicate our philosophical thinking?

Kant's metaphysical position before the first Critique of Pure Reason was close to Mendelssohn, but Kant was always very far from Jacobi's position; although Kant does have place for faith in his philosophy. Definitely, Kant had exchanged letters with both Mendelssohn and Jacobi. Perhaps the one philosopher in this context that Kant was not interested in at all was Spinoza. The spurious linking of Spinoza's philosophy and theology to Kant's first Critique of Pure Reason, (was I would claim), one of the main reasons that Kant was drawn in to the controversy (see Kant's Footnote \#6, page 19). Kant did not want to be linked with any of Spinoza's doctrines. Kant saw himself as contra Spinoza's fatalism, deism, and the denial of human freedom. Thus, the Pantheism Controversy provided the intellectual backdrop of Germany philosophy from 1780 until perhaps the death of F.W.J. Schelling's in 1854. Kant wanted to bring "reason" back to the table. 


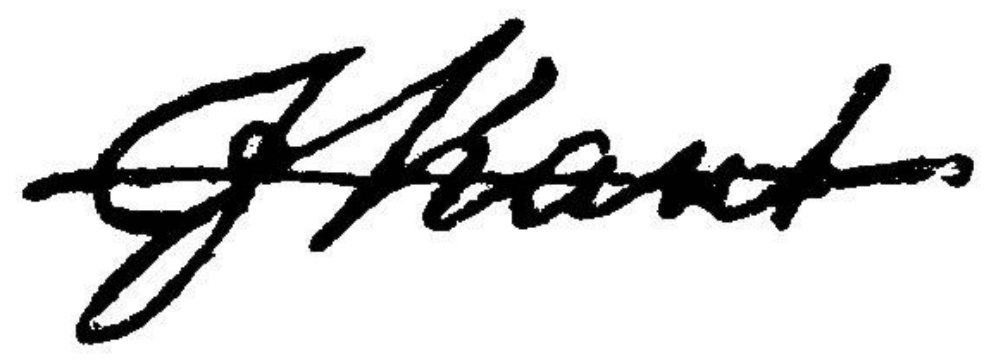

[Start of Immanuel Kant's Text in English translation]:

\section{What is meant to Orient Oneself in Thinking?}

We also may as high and advance in our concepts, and still so abstract from the senses, as they are still hanging but pictorial of representations (Vorstellung) whose real destiny is they that are otherwise not derived from experience to fit making of experience many other particulars. If we also wanted to give sense and meaning to our concepts (Begriffen) if they were not any intuitions (which is always a last example must be made of any of a possible experience) would be placed under? If we afterwards of this concrete understanding of action, the admixture of the image, first the random perception by sense, then so does the pure sensuous intuition in general be omitted: it remains that pure concept of the understanding is left, whose scope is now extended, and a rule of thought in general. In this way, even the general logic has come into existence, and some heuristic thinking method lies perhaps hidden in the experience of many other particulars of our intellect and reason, which, if we might understand them pull gently from that experience, philosophy, probably with some useful maxim could in rich abstract thinking. 
Such is the principle on which the Blessed Mendelssohn, as far as I know, only in his last writings (the Morning Hours pages 165-66, and the letters of Lessing's friends page 33 and 67) are explicitly known, namely the maxim of necessity, in the speculative use of reason (which he otherwise, trusted in respect of knowledge about supersensible (übersinnlicher) objects, much so even to the evidence of demonstration) by a certain line means that he called first the sense of community (Morning Hours), sometimes the healthy reason (gesunde Vernunft), sometimes based on the simple sense (in Lessing's friends). Who would have thought that this confession not only of its favorable opinion by the power of speculative should use reason are so fatal in matters of theology (which was indeed inevitable); but that even the vulgar common reason when ambiguity where it made the exercise of such property, in contrast to the speculation, would be in danger to serve basic proposition of enthusiasm and utter dethronement of reason? And yet this happened in the Mendelssohn and Jacobi dispute between them, mainly by the non-trivial conclusions of the ingenious author of the results; [Kant's footnote \#1] although I want either of them settle the intention to bring such a pernicious way of thinking in motion, but the latter company would rather see as argumentum ad hominem [Translator. Latin: argument attacking the person], which you can help yourself to mere opposition is well entitled to the nakedness which the opponents are to use to their disadvantage. On the other hand, I will show, that it is in fact merely the reason, not an alleged secret sense of truth, not effusive view under the name of faith (Glaubens), to which tradition or revelation (Offenbarung) can be no coincidence of reason (grafted). But as Mendelssohn steadfast and righteous zeal claimed only is the real pure human reason (reine Menschenvernunft), which he found it necessary and praised for orientation, whether though of course here be the high standards of speculative assets of the same, especially their own territory forming reputation (through demonstration) and disappear; and you, as far as it is speculative, nothing more than the business of cleaning (Reinigung) the common reason notion of contradictions, and the defense of their own 
sophistical attacks on the principles of common reason (must be left over). The enhanced specific and accurate concept of self-orienting may be helpful for us, the maxim of common reason in their processing, clearly represent the knowledge about supersensible (übersinnlicher) objects.

Orienting is in the proper meaning of the word: from a given region of the world to find (in the four we divide the horizon) the other, namely the rise. I now see the sun in the sky, and I know that it is now noon, so I know to find the south, west, north and east. For this purpose (Behuf) but I definitely need to feel a difference in my own subject, namely the right and left hand. I call it a feeling (Gefühl), because these two sides outward show in intuition no noticeable difference. Without this ability: in the description of a circle, without requiring him any difference of objects, but to distinguish the movement from the left to the right of the in the opposite direction, and thereby determine a difference in the position of objects a priori [Translator. Latin: from the earliest] I would not know if I put the west south points of the horizon to the right or to the left, and so should complete the circle through north and east to return to the south. So I orient myself geographically considering all given (Datis) sky but only by a subjective ground of distinction, and if in a day by a miracle all the constellations though incidentally the same shape and the very same position against each retained, except that the direction of the same, which otherwise east was, would now become the west, so would the next starry night though no human eye notice the slightest change, and even the astronomer, when he merely on what he sees and not at the same time what he feels overnight exist, would inevitably disorient. But so naturally to come to him which although created by nature, but familiar by frequent exercise discernment through feeling of right and left hands to help, and he will, if he only takes the pole star in the eye, not just notice the before the previous (vorgegangene) change, but also the same regardless of orientation can.

This geographical concept of the process, I can now expand, and among them are to orient themselves: in a given space at all, and therefore 
merely orient mathematically. In the dark, I orient myself in a room known to me, if I can only a single object whose location I have in mind touch. But here helps me obviously nothing but the determination of assets of the documents for a subjective distinguishing reason: because the objects whose place I should see, I see not; and if someone had indeed set myself the jest all items in the same order among themselves, but left what was right before, so I would be in a room where all the walls otherwise cannot be found (would the matter). But as soon as I am guided by the mere feeling a difference in my two sides, the right and the left. That is what happens when I'm on my otherwise known streets where I now distinguish no house, going in the nighttime, and I able to contact.

Finally, I can extend this concept even more, as he then considers in the concerning, not only in space, i.e., mathematically, but even in thought, that is, logical guidance. One can by analogy easily guess that this will be a business of pure reason to guide their use, when they start intending to expand beyond all limits of experience of familiar objects (of experience), and utterly no object of intuition place, but only room for the same; since it no longer is then able to objective reasons of knowledge, but only to a subjective distinguishing fact in determining their own judgment to make their judgments under a certain maxim [Kant's footnote \#2]. This subjective medium, then still left is none other than the feeling of reason's requirement (als das Gefühl des der Vernunft eigenen Bedürfnisses). You can stay safe from all error, if one be underpins not to judge where you do not know as much as is required to determined judgments. So is ignorance of the cause, although the barriers, but not the errors in our knowledge. But where it is not as arbitrary, if one wants to determine judging something or not; where a real requirement and probably even one which attaches itself to the reason that makes judgments necessary, and yet lack of knowledge in regard to the restrict ourselves to the judgment required pieces: a maxim as is necessary according to which we make our judgment, for the reason one wants to be satisfied. When is it previously agreed that there is no conception of the objects could not even here to give something to this similar, which we represent our extended terms to their proper object, and 
so they could secure their real due to chance: it is not for us continue to do until left: to consider first the term with which we want to dare us about any experience if it was also free of contradictions (Widersprüchen), and then at least the ratio of the object to the objects of experience under to bring concepts of the pure understanding, which we are not even sensualize, but also supersensible (Übersinnliches), at least suitable to experience many other particulars of our reason; think, for without this precaution, we would be able to make no use of such terms, but rather, raving (schwärmen) instead of thinking.

By this means alone, namely, by the mere concept, but nothing is in regard to the existence of this object and the actual link it with the world aligned (the totality of all objects (Gegenstände) of possible experience). But now comes the right of need a reason, as a subjective reason to assume anything and to accept what they cannot presume to know by objective reasons, and consequently, in thinking; fill the thick night for us in the vast space of the supersensible (Übersinnliches) only by their own need to orient.

There may be some supersensible (Übersinnliches) thinking (because objects of the senses but do not fill the whole field of all possibility) where reason nevertheless feels no need to expand to the same, much less to accept its existence. The reason is to identify causes in the world, what the senses reveal themselves (or at least are of the same type as so reveal them), employment enough to still have the effect of pure spiritual beings of nature to whose purpose (Behuf) is necessary; in an acceptable (Annehmung) whose rather their total need would be harmful. For as we of the laws according to which like meaning (würken) such essence (Wesen), know nothing, but of those, namely the objects of the senses, know much; yet can at least hope to learn: so would the use of reason rather happen through such final condition. So there is no need, rather, it is a mere curiosity, which runs on nothing but daydreaming, to investigate after it, or to play with fantasies (Hirngespinsten) of the kind. It is quite otherwise with the terms of a first primary being (Unwesen), as the highest 
intelligence and at the same time as the highest good being applied (bewandt). For not only that our reason already feels a need the notion of the concept unrestricted (Uneingeschränkten) everything limited (Eingeschränkten), and therefore all other things [Kant's footnote \#3], to lay the foundation so have we this need on the condition of the existence of the same, without which they are of the contingency of the existence of things in the world, least of all from the convenience and order that one in so admirable grade (on a small scale, because it is close to us, even more, as in the great) everywhere encounters can specify no satisfactory reason. Without an intelligent author can assume without falling into nothing but inconsistence (Ungereimtheiten), at least no understandable specify reason for it, and whether we have the impossibility of such expediency same without a first sensible reason cannot prove (for then we would have sufficient objective reasons this assertion, and it would not be subject us to rely on the subjective) as a frugal subjective due to the remains of this lack of insight acceptable (Annehmung) same is that the reason it needs: to put something ahead of you is understandable presupposes this to explain it phenomenon, since everything they can connect only one term otherwise, this need is not rectified.

But you can view the need of reason as twofold: first place in their theoretical, secondly, in their practical use. The first need I have just quoted, but you can see very well that it was only conditionally, that is (d.i. or das ist), we must accept the existence of God, when we talk about the first all accidental causes primarily in the order really out in the world use, want to judge. Far more important is the need of reason in its practical use, because it is absolutely, and we put forward the existence of God are not only compelled then, if we want to judge, but because we have to judge. Because of the pure practical use of reason is the regulation (Vorschrift) of moral laws. But they all lead to the idea of the highest good, which is possible in the world, so far it only through freedom is possible: the morality, of the other side on that which does not merely on human freedom, but also on the nature matters, namely, to the greatest happiness, provided it is distributed in proportion to the first. Now requires reason, 
such a dependent highest good, and for the good sake to take that a highest intelligence as the highest independent: not in order of the unifying image of the moral law, or the driving force for their observation to deduce (because they would not have moral value, if the reason for movement of something else, as if derived from the law alone, that's categorically for themselves certain); but only to give the concept to prevent the highest good objective reality, that is, that to be held (zusamt) all morality will not be held for only a mere ideal, if the inseparable idea of which accompany the morality existed nowhere.

It is not knowledge, but felt before [Kant's footnote \#4] need from reason, whereby Mendelssohn (without his knowledge) oriented in speculative thought. And, since this line means not an objective principle of reason, a principle of insights, but a merely subjective (that is, a maxim) of their own allowed by their place use, a corollary of the need and of itself throughout the determining ground of our judgment accounts about the existence of the highest Being (des höchsten Wesens), from which it is only a casual use to orient themselves in the speculative attempts on the same subject: Mendelssohn lacked herein, however, that he still dare to (zutraute) this speculation so much wealth for alone on the align road to demonstrate everything. The need of the former agent could find instead when the inadequacy of the latter was fully conceded: a confession, to which it his insight at last would have been if a longer lifespan (the teenage years more own agility of mind), old easily switch to change habitual way of thinking to change the state of the science (Wissenschaften), would have been allowed (vergönnet). However, it remains the merit that he insisted: the last touchstone of admissibility of a judgment here, as everywhere, nowhere, than to look for alone in reason, whether it liked it by insight or mere need and the objectives of their own wholesomeness in their choice of their principles (Sätzes) are passed. Mendelssohn cited the reason in its latter many other particulars, the common human reason (gemeine Menschenvernunft), because this is their own interest at any time first in mind; however, one of the natural tracks must already be entered to forget 
that, and pointless to peek under terms in an objective consideration to only his knowledge, it may be necessary or not to expand.

But as the expression: statement of sound reason, in the present question is still ambiguous, and either as himself misunderstood Mendelssohn, for a judgment of reason, insight, or, as seems to me the author of the results to take, a judgment from reason inspiration can be taken: it will be necessary to give this source assessing a different name, and it is not more appropriate than that of a rational faith (Vernunftglaubens). Every belief, even the historical, indeed must be reasonably, (because the last touchstone of truth is always the reason); alone a rational faith is that which is founded on no other data than that so contained in pure reason. All faith is now a subjectively sufficient, but objectively with consciousness insufficient to assent, so it is the opposite knowledge. On the other hand, if for objective, although whether lack of awareness, held true for some reasons; therefore, merely though (gemeinet) may be my one, but by gradual addition in the same kind to be of reasons finally knowledge. In contrast, if the grounds of belief by their nature are not objectively valid, faith can be never knowledge by any use of reason. The historical belief as of the death of a great man, the report some letters can be a knowledge, if the authority of the same place, his funeral, reports etc. testament. Therefore, something that historically held only to certificates for true, that is, believed, for example, that Rome is a city in the world, and yet one who can never been there say: I know, and not just: I believe that there a Rome exists: which is quite well together. In contrast, the pure can sense belief by all naturally data (Translator note. German word: Data) of reason and experience never know be changed, because the reason of belief here merely subjective, that is a necessary requirement of reason (and as long as we are human, will always remain) only presuppose the existence of a highest Being -- not to demonstrate. This need of reason to satisfactory theoretical many other particulars would nothing other than to be pure rationality hypothesis (reine Vernunfthypothese), i.e., an opinion which would be insufficient to assent to subjective reasons, therefore, because one given to explain effects can never expect other than this basic 
and the reason it requires a basic explanation. In contrast, the rational belief, based intention on the need of their use in practical, a postulate of reason (ein Postulat der Vernunft) could be: not as if it were an insight that would do for all certain enough the logical requirement, but because of this holding for true (if in the humans all is only morally well-ordered) the degree of knowledge inferior to none [Kant's footnote \#5]; whether the kind (der Art) after it is equal to fully distinguished.

A pure reason faith is the guide or compass, which the speculative thinker based on his rational quarreling (Vernunftstreifereien) in the field of supersensible objects, man of common but (morally) sound reason but his way, and probably in theoretical as practical point of view, the whole purpose of his may prefigure determination entirely appropriate, and it is this rational faith, which must be placed at the foundation of every other faith, yes every revelation (Offenbarung).

The concept of God, and even the conviction of his existence, can only be found in reason alone, go out alone from Him, and neither inspiration nor by a given message, no matter how big of authority (Auktorität) first come to us. Wider tracking by me an immediate intuition of such a nature, as they nature, as far as I know, cannot deliver me: nevertheless a concept of God must serve as a guideline, whether this phenomenon agree with all the what is necessary for the characteristic of a deity (Gottheit). Now, I now no one before, how is it possible that any appearance that of even the quality of performing whatever just think, never makes but look: it is but at least that much clear that: just to judge whether God, which seems to me what internal or external impact on my feeling, I keep him on my rational concept of God, and afterwards had to check, if it was not this adequately, but only if it did not contradict God. Just so: if even at all, which he discovered me immediately, nothing was found, contrary to what that concept: nevertheless would this phenomenon, intuition, immediate revelation (unmittelbare Offenbarung); or how else will call such a representation, the existence of a being [Translators note: essence, Wesens) never prove the concept (if not unsafe determined, and 
therefore the admixture to be subjected to all sorts of madness), infinity according to the size enjoins distinction of all creatures, but which terms have no experience or intuition adequately, and therefore can never the existence prove of such a being unambiguously. The existence of the highest Being (höchsten Wesens), so no one can by some intuition first be convinced, the rational faith (Vernunftglaube) must precede, and then could possibly certain phenomena or openings give rise to investigating whether we use what speaks to us, or represents us well are authorized to keep divinity and after being confirmed that belief (Glauben).

So if reason in matters that concern about sensuous objects, as the existence of God and the future world, their right, granted first to speak, is disputed: as all fanaticism, superstition, and even the atheism (Atheisterei) has opened a wide gate. And yet seems in the Jacobian and Mendelssohnian dispute [or controversy] everything on this upsetting, I do not know if just the rational insight and knowledge (supposed by strength in the speculation), or as even the rationality of faith (Vernunftglaubens), and created against the establishment of another faith, the one everyone can do as he pleases. You should almost close to the latter, if the one Spinoza's only concept of God, coherent with all the principles of reason, [Kant's footnote \#6] yet the reprehensible term looks set. Because if it is very well tolerate the same with the faith of reason to grant: that speculative reason itself, not even the possibility of a being (Wesen), as we should have to think of God, to see the stands: it can but with even no faith, and everywhere coexist with any assent to an existence that reason even the impossibility see an object, and yet, from other sources, the reality could recognize the same.

Men of mental abilities and attitudes of extended! I admire your talent and feel love your people. But you also probably think about what you are doing, and where it wants to reason out with your attacks? Without a doubt you will, that freedom to think will get unmolested, for without this it would soon have yourself with your free turns of genius to an end. We 
want to see what would become of this freedom of thought naturally, if such a process, you begin out of hand.

To think of freedom is first place, opposite the bourgeois compulsion. Of course, it is said: the freedom to speak, or write, could force us through top, but not to be taken by them the freedom to think. However, how much and with what accuracy we would probably think, if we do not speak in community with others, we would think their thoughts are notified! So you can say that that external violence, which the freedom his thoughts publicly notified, the people snatches them the freedom of thinking: resist the only treasure (Kleinod) that all civic burdens still remains for us and which alone all the ills of this state, and counsel can be taken.

Second, the freedom to think even taken to mean that it is the compulsion of conscience is opposed, where without any external force in matters of religion citizens pose to guardians over others, and instead of argument by prescribed, with anxious fear of the risk of their own examination accompanied creeds all examination of reason by early impression know to banish the spirits.

Third, also means freedom of thought, the subjugation of reason under any other laws, as: they are themselves, and their opposite is the maxim of a lawless use of reason (by the way that the genius mentioned, continue to see than under the restriction by law). The result is more natural this way: that if the reason does not want to be subjected to the laws that they are themselves, they must bow to the yoke of laws, which gives your another, for without any law can do nothing, not even the biggest nonsense that propel its game long. So is the inevitable result of the declared lawlessness in thinking (an exemption from the restrictions imposed by reason) this: that freedom to think, last lost thereby, and because not as misfortune, but rather true arrogance (wahrer Übermu) is to blame, in the true sense of the word will be forfeited. 
The course of events is about this. First, the genius like much in its bold sweep of as it has the thread, what else drew reason stripped. It soon charmed by other power spells and great expectations, and seems to have now set them on a throne, the slow lumbering reason graced (zierete) so bad, and it nevertheless always leaded the same language. The maxim then adopted at the top of the invalidity of a legislative reason we call common people fanaticism (Schwärmerei, enthusianism); those favorable of good nature but enlightenment. Because, however, must soon arise from a confusion of tongues among these yourself because by reason alone can command valid for everyone, now follows each of their inspiration: they must last from inner promptings outside through testimonials proven facts (Facta), from traditions that were initially selected itself, with the time forced upon certificates, in a word, the entire submission of reason facts (Facta), i.e. the superstition arise because of this but at least in a legal form and can thus bring to a retirement (Ruhestand).

Because however the human mind still strives for freedom: it must, at once break the shackles, their first use of a long unaccustomed freedom in abuse and presumptuous confidence degenerate to independence of their assets of any restriction, in a persuasion of the autocracy of the speculative reason that accepts nothing but what by objective reasons can justify and dogmatic belief, but everything else boldly denies the way (wegleugnet). The maxim of the independence of reason from their own need (do without (Verzichttuung) rational faith) is now unbelief: not a historical, for the one cannot be. Therefore, not thought of as deliberately as sane (because each one fact, which proved just enough is just as well having to believe as a mathematical demonstration, whether he likes it or not), but a reason unbelief, a predicament of condition of the human mind, of the moral laws first all the power of the driving forces on the heart, with the time to do them yourself behaving all authority, and causes the mentality that you free thinking (Freigeisterei) calls, that is, the principle of recognizing no more duty. Here now mixes the authorities into play, that's not civil matters come into the greatest disorder itself, and because the nimble (behendeste) and yet emphatic means is you just the best, it raises the freedom to think even 
on, and submits this, the same other trades, the national regulations. And so destroying freedom of thought, so even if they want to proceed independently of the laws of reason. Finally, the friends of the human race and of what is holiest to them! Accept in what seems to you after careful and honest examination most credible, it may now facts (Facta), it may be rational grounds (Vernunftgründe), and only denies the reason is not what makes it the highest good on earth, namely the privilege from the last touchstone to be of the truth [Kant's footnote \#7]. Adverse if you will, this freedom unworthy, they also certainly lose, and in addition pull this disaster the rest of the innocence parts on the neck, which would have been otherwise well disposed to their freedom lawful, and thus appropriate to use the world's best!

(Translator. German text for the last sentence. "Widrigenfalls werdet Ihr, dieser Freiheit unwürdig, sie auch sicherlich einbüßen und dieses Unglück noch dazu dem übrigen schuldlosen Teile über den Hals ziehen, der sonst wohl gesinnt gewesen wäre, sich seiner Freiheit gesetzmäßig und dadurch auch zweckmäßig zum Weltbesten zu bedienen!”)

Königsberg.

I. Kant

Kant's own footnotes. Labeled in the text as [Kant's footnote \#].

(1). Kant's Footnote \#1. Jacobi, On the doctrine of Spinoza in Letters to Moses Mendelssohn. Breslau 1785. - Leipzig 1786. Results of the Jacobian and Mendelsshohnian Philosophy by a Volunteer. [Translator note: by Wizenmann] 
(2). Kant's Footnote \#2. Orient oneself in thinking in general, therefore to say: be determined, at the inadequacy of the objective principles of reason, in holding true for a subjective principle the same (Sich im Denken überhaupt orientieren, heißt also: sich, bei der Unzulänglichkeit der objektiven Prinzipien der Vernunft, im Fürwahrhalten nach einem subjektiven Prinzip derselben bestimmen).

(3). Kant's Footnote \#3. Since the reason for the possibility of all things necessary to presuppose reality as given, and consider the diversity of things only as barriers by them pendant negations: it sees itself compelled one possibility, namely that of the full system set than originally at the foundation, but to look at all other than derived. Since the consistent ability of each thing well in the whole of all existence must be found, at least, the principle of complete determination makes the distinction of what is possible from reality our reason only possible in this way: we find a subjective ground of necessity, that is, a need our reason itself, all the way to lay the existence of all most real (allerrealesten) (highest) being (Wesens) the foundation (Grunde). So now stems from the Cartesian proof of the existence of God, by subjective foundation (Grunde) to put something for the use of reason (which is basically always remains only an experience of use) predicted for objectively - hence need for insight are held -. So it is with this, so it is with all the evidence of the worthy Mendelssohn let it be (bewandt) in his Morning Hours. They do nothing for the sake of demonstration. Therefore, they are but by no means useless. For not to mention give what beautiful occasion this highly ingenious evolutions of the subjective conditions of use of our reason to the full realization of this our assets as to which purpose (Behuf) they are lasting examples: so is the assent to subjective foundations (Gründen) of the use of reason when our objective lacking and we are compelled nevertheless to judge, still of great importance, we only need what only wrung (abgenötigte) requirement is not for free access to spend to the enemy, with which we again dogmatizing have admitted, not without distress weaknesses perform, which he can use to our detriment. Mendelssohn was thinking no doubt that the dogmatizing the straight path to philosophical 
fanaticism (Schwärmerei) is the pure reason in the field of the supersensible (Übersinnlichen), and that very same reason only criticism assets could remedy this evil thoroughly. It is true that the discipline of the scholastic method (e.g. the Wolfian, which he also counseled about), since all terms determined by definitions and all steps must be justified by ground principles (Gründsätze), really inhibit this nonsense for a while, but by no means entirely prevent. For with what rights you want the reason, it's time to in that field and it's own admission, succeeded so well, denied in precisely the same to go further? and where is the boundary, where it must stop?

(4). Kant's Footnote \#4. Reason does not feel, it does their lack, and acts by the desire for knowledge, the feeling of need. It is hereby as be applied (bewandt) with the moral feeling, which caused no moral law, because this springs entirely from reason, but by moral laws (Gesetz), and consequently by reason, is neither caused nor earned by the lively and yet free will requires certain foundations (Gründe, or reasons).

(5). Kant's Footnote \#5. For the strength of faith is the consciousness of its immutability (Unveränderlichkeit). Now I can be quite certain that nobody the sentence (Satz): there is a God, will and can disprove, for where does he want to take (hernehmen) this insight? Therefore, it is with the faith of reason (Vernunftglauben), not as be applied historical, in which it is still possible that evidence would be found to the contrary, and where you have subject still, to change your mind, [indeed] if our knowledge of the matters should expand.

(6). Kant's Footnote \#6. It is hard to understand how scholars thought in the Critique of Pure Reason could find to advance for Spinozism. [Translator note: this could be the primary reason Kant decided to write this essay]. The criticism cuts to the dogmatism completely the wing (die Flügel) in respect of knowledge about supersensible (übersinnlicher) objects, and Spinozism is herein dogmatic; that he even competes with the mathematicians in respect to the severity of the proof. The criticism proves, 
that the board (die Tafel, or tablet) of the pure conceptions of the understanding (reinen Verstandesbegriffe) must include all materials of pure thought, Spinozism speaks of thoughts, thinking it itself, and therefore, of an accident that it exists as a subject of its own: a concept (Begriff), which in itself human understanding is not and cannot bring into it. The criticism shows it not long rich to assert the possibility of a self imaginary being to that in his words nothing contradictory (although it then remains necessary, however, allowed to accept this possibility) of Spinozism is but to request access to the impossibility of a being whose idea consists of nothing but pure concepts of the understanding, of which only one has separated all conditions of sensibility (Sinnlichkeit), in which therefore never a contradiction can be found, and yet nothing able to support this presumption (Anmaßung) by going beyond all boundaries. Precisely for the sake of this leads straight to the enthusiasm of Spinozism. In contrast, there is no single sure way to eradicate all enthusiasm by the root, as those limiting the determination of pure rational faculty (Vernunftvermögens). - Just so find another scholar in the Critique of Pure Reason, a skepticism, although the criticism it just goes to put something certain and definite proof as to the scope of our a priori knowledge. In the same dialectic in critical investigations, but which are designed to make the inevitable dialectic, which everywhere the dogmatic pure reason guided and caught themselves and entangled to dissolve and destroy forever. The Neo-Platonists, the Eleatic called themselves, because they knew how to find their own grill (Grillen) in older authors, if they had carried into those before, just been proceeded; therefore, it happens insofar nothing new under the sun.

(7). Kant's Footnote \#7. Even thinking is the upper touchstone of truth in themselves looking (i.e., in its own reason), and the maxim any time to think for themselves is Enlightenment. Which now include, as much not as imagine ones which set the Enlightenment in knowledge, since it is a negative principle in the use of its faculty of knowledge and rather more of so to literacy is also rich in the use of which is the least enlightened. Of their own to say more, than all the things you should take, ask yourself 
nothing use reason: if you would probably find feasible, the reason why we assume something, or the rule that from what you assumed to follow to make the general basic propositions of their use of reason? This test can do each with him, will see superstition (Aberglauben) and fanaticism ((Schwärmerei, enthusianism) in this test soon disappear if it has not the same by far the knowledge to refute both for objective reasons. For it uses only the maxim of self-preservation of reason. Enlightenment in individual subjects to establish through education, so quite easily: one only has to begin early to accustom young minds to this reflection. But an era enlighten is very lengthy, for it can be found much external obstacles that prohibit some of those training system, and partly impeded (Ein Zeitalter aber aufzuklären, ist sehr langwierig; denn es finden sich viel äußere Hindernisse, welche jene Erziehungsart teils verbieten, teils erschweren).

Königsberg.

I. Kant.

[Final page of Immanuel Kant's text in English translation].

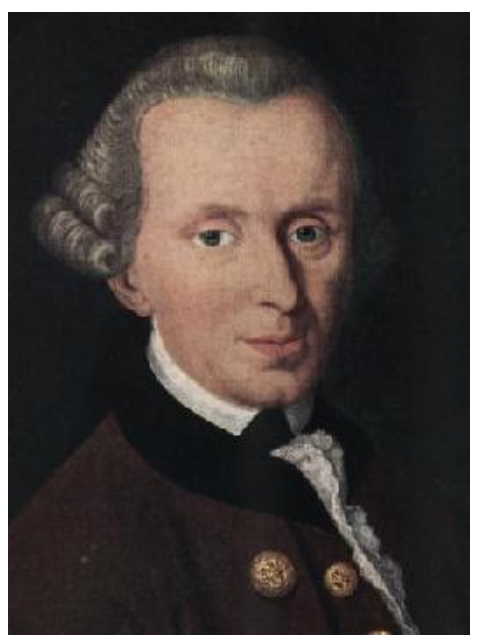


Final page: Kant: AA VIII, Was heißt: Sich im Denken. Seite 147. Page 147. (AK 8:147). Published in October 1786.

\title{
Translation copyright @2014 Daniel Fidel Ferrer.
}

\author{
All rights reserved. Free unlimited distribution.
}

Creative Commons General Public License "Attribution, Non-Commercial", version 3.0 (CCPL BY-NC). 


\section{Translator's remarks by Daniel Fidel Ferrer}

My translation is closer to Kant's actual written text than most of the other translation; therefore, I did not re-write Kant to help the reader better understand Kant. I did not "fix" Kant's text. I have generally followed Kant's punctuation and paragraphs as well. The text is difficult and I have add some ( ) to handle some of Kant's long sentence. All translations are an interpretation - even mine. I make no claim that my translation is better than previous translations. Some of the other these texts are not translations at all, but are in fact re-writes in English. Given the difficult of the German text, this approach makes some sense for readers of Kant in English. Remember this was written in style of academic philosophy in Germany in 1786.

I strongly suggest you learn German and try not to depend on translators; or, read all available German to English translation and use them all. By the way, conversational German is not the answer to reading Kant's text. Work and re-work on the translations of Kant's text. This translation is still green and the opposite of pauca sed matura (Latin for: few, but ripe). Do not worry, I am still learning too. Caveats are too many: I am not a native speaker of German, I do not know conversational German, I do not teach the German language, I am not a philologist, Kant is not easy in German, Kant's German is over 225 years old, Kant's German is in a nice word: scholastic and the sentences are overly long. In addition, I am not a professional translator. Martin Luther who did the famous translation of the Bible into German wrote in a letter, "If anyone does not like my translation, they can ignore it... (September 15, 1530)". I did this translation to learn more of Kant's German and to appreciate the text. This essay highlights the background of Kant's philosophical development during the pantheism controversy. Of course, this has added to my greater understanding of the later development of Kant's philosophy; in particular, the development and genesis of Kant's thinking for his next

major projects: the Critique of Practical Reason, $\left(2^{\text {nd }}\right) 1788$; and even more 
important for the origin and background of the Critique of Judgment $\left(3^{\text {rd }}\right)$, 1790. Who was Kant engaged with attacking? What were the questions that Kant was opening? What did Kant want to achieve in the last Critique?

Kant's text remains open to interpretation, learning, and to thinking. Two dominant approaches to Kant, the first is getting Kant right and this belong to Kantian Philology (according to Heidegger); the second belongs to thinking with Kant and this belong to Kantian philosophy.

Kant's essay appears to be very abstract for many readers. Do not be taken back; but rather think in sprint of Nietzsche, who said, "Abstract thinking for many, is a hardship, for me, on good days, a feast and a frenzy". [Nietzsche's notebooks -1885; 34 [130]. April-Juni 1885; "Das abstrakte Denken ist für Viele eine Mühsal, für mich, an guten Tagen, ein Fest und ein Rausch.”]. Go for the feast and frenzy. Let Kant speak in 2014 and beyond. Do not let would be philosophical logomachies stop Kant from speaking or trying to expatriate Kant to the dustbins of history. We can never go around Kant. 


\section{Notes and background for Kant's essay and translation.}

"What does it mean to orient oneself in thinking?"

By Immanuel Kant (1724-1804).

"Was heißt: sich im Denken orientieren?"

Berlinische Monatsschrift (October 1786), pages 304-30.

Berlinische Monatschrift. 1783-1811 (full scan of text for these years).

http://www.ub.uni-bielefeld.de/diglib/aufkl/berlmon/berlmon.htm

Immanuel Kant: AA VIII, AK 8: 131 to AK 8:147. "Was heißt: sich im

Denken orientieren?" Academy Edition of Kant (AK). Elektronische

Edition der Gesammelten Werke Immanuel Kants. Normal citation format is $\mathrm{AK}$, volume, and page number.

In this case, the essay is Immanuel Kant, AK 8:131 to 8:147.

From AK Volume 8, title page, page 131:

http://www.korpora.org/Kant/aa08/131.html

To AK Volume 8, last page, page 147:

http://www.korpora.org/Kant/aa08/147.html

General collection of Kant's text in German (AA or AK)

Volumes 1-23.

http://www.korpora.org/Kant/ 


\section{Some earlier translation from German into English of Immanuel Kant's essay.}

Translated by Allen W. Wood in Immanuel Kant: Religion and Rational Theology, edited and translated by Allen W. Wood and George di Giovanni (Cambridge University Press, 2001), pages 7-18. See the excellent introduction about context of this essay by the translator, pages 3-6.

Translated by H. (Hugh) B. (Barry) Nisbet in Immanuel Kant: Political Writings, edited by Hans Reiss, 2nd ed. (Cambridge: Cambridge University Press, 1991), page 237-49.

Also, see Kant earlier essay in the same journal with my translation. 1784. "Answer the question: What is Enlightenment?" By Immanuel Kant. New English translation and notes by Daniel Fidel Ferrer (2013). At this web URL:

https://archive.org/details/AnswerTheQuestionWhatIsEnlightenment 


\section{Pantheism Controversy (Quarrel) (Pantheismusstreit)}

Kant's philosophy and theology is entangled in the following positions both for and against. Indeed, other lesser-known philosophers are in-between Kant and these different philosophical positions. For example, Johann Georg Sulzer (1720-1779) (Wolffian and translator of Hume An Enquiry Concerning the Principles of Morals into German in 1755), Johann August Eberhard, (a Wolffian, 1739-1809), and Johann Georg Heinrich Feder (1740-1821). Johann Hamann wrote to Johann Herder in 1779, that Kant always had books of Johann Nikolaus Tetens, (1736-1807) open on his desk (he was a well-known German follower of Hume). These are just to give you some basic 'signs' on the way to building a comprehensive view of Kant and his philosophy as it developed in the context of these philosophers. In other words, the interweaving and currents of the intellectual period of $1785 \mathrm{~s}$ is in reality a lot more complex than just these simple -isms; but these can be used as some guideposts as you make your own way. Nevertheless, you must get beyond mere philosophical labels, as I think F.W.J. Schelling is the one philosopher who understood this insight best when he wrote:

"It cannot be denied that it is a splendid invention to be able to designate entire points of view at once with such general epithets. If one has once discovered the right label for a system, everything else follows of its own accord and one is spared the trouble of investigating its essential characteristics in greater detail. Even an ignorant person can render judgment upon the most carefully thought out ideas as soon as they are presented to him with the help of such labels. But, after all, in an extraordinary assertion of this kind, everything depends upon the closer definition of the concept." (from Philosophical Investigations into the Essence of Human Freedom, 1809, translation by Joan Stambaugh). 


\section{Kant's philosophical thinking was against these movements.}

Against the Sturm und Drang (Storm and Urge (stress) movement (especially, Kant's former student - Johann Herder and also Kant's friend Johann Hamann)

Against Pantheism (Lessing, Spinoza)

Against Skepticism (Hume)

Against Rationalism (Leibniz's version)

Against Faith (Glaube, the German word for: "faith" or "belief"), revelation and mysticism (Jacobi)

Against fanaticism or enthusianism (Schwärmerei)

Against Common sense (Mendelssohn's version)

Against rational metaphysics

Against Dogmatism (Wolff, at least the Kantian version of Wolffian dogmatism)

Against rational metaphysics (attacked by Kant in 1st Critique of Pure

Reason)

Against Spinoza (atheism, nihilism (word first used by Jacobi), fatalism, no personal God)

Deism vs. Theism

Against the Spinoza's nonanthropocentrism

Against Systems as such (in Spinoza's and Descartes's view)

Against freedom (Spinoza's denial of free will)

Against some version of Johann Hamann's countering Rationalism with Awakening (Enweckung)

Contra: Immanuel Kant used the expression "rational faith" (Vernunftglaube). 


\section{Chronology of the Pantheism Controversy (Quarrel) (Pantheismusstreit)}

\section{Section 1. Main philosophers and authors. Ranked by birth year.}

René Descartes (1596-1650)

Baruch Spinoza (1632-1677)

John Locke (1632-1704)

Gottfried Wilhelm von Leibniz (1646-1716)

Christian Wolff (1679-1754)

Hermann Samuel Reimarus (1694-1768)

------ Daughter, Elise Reimarus (1735-1805)

Alexander Gottlieb Baumgarten (1714 -1762)

Johann Melchior Goeze (1717-1786)

Johann Wilhelm Ludwig Gleim (1719-1803)

Immanuel Kant (1724-1804)

Gotthold Ephraim Lessing (1729-1781)

Moses Mendelssohn (1729-1786)

Johann Georg Hamann (1730-1788)

Friedrich Heinrich Jacobi (1743-1819)

Johann Gottfried von Herder (1744-1803)

Markus Herz or Marcus Herz (1747-1803)

Johann Erich Biester (1749-1816)

Salomon Maimon (1753-1800) [Salomon ben Josua Maimon]

Karl Leonhard Reinhold (1757-1823)

Thomas Wizenmann (1759-1787)

Jakob Sigismund Beck (1761-1840)

Gottlob Ernst Schulze "Aenesidemus" (1761-1833)

Johann Gottlieb Fichte (1762-1814)

Friedrich Immanuel Niethammer (1766-1848)

August Wilhelm Schlegel (1767-1845)

Friedrich Daniel Ernst Schleiermacher (1768-1834)

Johann Christian Friedrich Hölderlin (1770-1843)

Friedrich Karl Forberg (1770-1848)

Georg Wilhelm Friedrich Hegel (1770-1831)

Karl Wilhelm Friedrich Schlegel (1772-1829) 
Friedrich Wilhelm Joseph Schelling (1775-1854)

\section{Section 2. Lessing's first quarrel. Fragments Controversy.}

Fragments Controversy (Fragmentenstreit)

1774-1778. Fragments by an Anonymous Writer (Wolfenbüttel Fragments). By Hermann S. Reimarus (1694-1768). Zur Geschichte und Literatur. Deist writings, published anonymously by G.E. Lessing. Started the Fragment Quarrel (Fragmentenstreit). Lessing was famously attacked by Johann Melchior Goeze (17171786).

1775. Philosophical Conversations. By Mendelssohn

1778. On the Aims of Jesus and His Disciples (Von dem Zwecke Jesu und seiner Jünger). By Reimarus. Published by Lessing.

1779. Nathan the Wise (Nathan der Weise). Is a play by Lessing, written in winter of 1778-1779. Note: this play takes place during the Third Crusade in Jerusalem in the year 1192 .

\section{Section 3. Pantheism Controversy or Pantheism Quarrel starts.}

1780. July $5-6^{\text {th }}$ in Wolfenbüttel, which is a town in Lower Saxony, Germany, located on the Oker River. Jacobi meets and held discussions with Lessing (who was the librarian at the Wolfenbüttel library [Duke of Brunswick's Herzog-August-Bibliothek]. Lessing makes two unforgettable remarks that really stings Jacobi. The first remark is about theology and his expression was "One and All" (Greek is "hen kai pan" ["Ev Kaì $\Pi \tilde{\alpha} v])$; this means pantheism. Second remark is that Lessing said, "There is no philosophy other than Spinoza". This is the starting point and core of the whole Pantheism Controversy. What does this mean for philosophy? Many philosophers in Germany at the time considered Spinoza to be an atheist. Following an atheist was very controversial.

Lessing died in February 15, 1781 at age 52.

1781. Critique of Pure Reason (Kritik der reinen Vernunft) $\left(1^{\text {nd }}\right.$ edition or the so-called A-edition). By Kant. (AK 4:1-252). Kant's own personal marginalia is recorded at AK 23:17-50. Bound copy of the famous book arrives for Kant's breakfast July 22, 1781. Kant was living in apartment on Ochsenmarkte, Königsberg, which was the capital of 
the Kingdom of Prussia at that time. Now the city is called Kaliningrad and it is in the Russian Federation. This book is called the first Critique (two more were written).

1783. Draft for the Prolegomena. Vorarbeit zu den Prolegomena zu einer jeden künftigen Metaphysik (AK 23:51-65). By Kant. These are part of Kant's notes against the Garve (written) and Feder (edited) review published 19 January 1782 of the Critique of Pure Reason. The first shorten review was published in the Zugabe zu den

Göttischen Anzeigen von Gelehrten Sachen (Göttingen Learned Advertiser) and was published anonymously; and the original and longer version published in the Allgemeine Deutsche Bibliothek (General German Library) [Volumes XXVII-LII, part II, pages 838-62]. See Garve's letter to Kant of 13 July 1783.

1783. Prolegomena to any Future Metaphysics that will be able to come forward as a Science (Prolegomena zu einer jeden künftigen Metaphysic, die als Wissenschaft wird auftreten können). By Kant. (AK 4:253-383).

1783. Kant moves into his own house 87-88 Prinzessinstraße.

1785. September. On the doctrine of Spinoza in Letters to Moses Mendelssohn (Über die Lehre des Spinoza in Briefen an den Herrn Moses Mendelssohn). By Jacobi. This was about Lessing being a follower of Spinoza and a follow up to their discussions of 1780 .

1785. October 16. Letter to Kant from Moses Mendelssohn. "Though I no longer have the strength to study your profound writings with the necessary concentration, I recognize that our basic principles do not coincide. But I know too that you tolerate disagreement, indeed that you prefer it to blind worship. From what I know of you, the intention of your Critique is just to drive blind worship out of philosophy. Apart from that, you permit everyone to have and to express opinions that differ from your own." Later in the letter: "All in all this work of Herr Jacobi is an unusual mixture, an almost monstrous birth, with the head of Goethe, the body of Spinoza, and the feet of Lavater." [AK 10:413-414].

1785. October. Morning hours or lectures about God's existence. (Morgenstunden oder Vorlesungen über das Dasein Gottes). By Mendelssohn.

1785. October-November-December. Mendelsshohn is writing the book To Lessing's Friends.

1786. To Lessing's Friends (An die Freunde Lessings). By Mendelsshohn (published posthumously). He took this manuscript to his publisher Voss and Sohn, and in the 
process forgot his overcoat on December 31, 1785; and he caught a cold and died. The popular newspaper account was that Jacobi had caused Mendelsshohn death. Mendelsshohn died January 4, 1786 in Berlin.

1786. January. Metaphysical Foundations of Natural Science (Metaphysische Anfangsgründe der Naturwissenschaften). By Kant. (AK 4:465-565).

1786. 7 April. Kant's letter to Marcus Herz. (AK 10:442-443). Signed: most obedient faithful servant, I. Kant. Kant writes, "The Jacobi controversy is nothing serious; it is only an affection of inspired fanaticism? trying to make a name for itself and is hardly worthy of a serious refutation. It is possible that I shall publish something in the Berliner Monatsschrift to expose this humbug (Gaukelwerk or deception)."

1786. 11 June. Johann Erich Biester's (one of Kant's friends and editor, 1749-1834) wrote a letter to Kant. (AK 10:453-458). This letter finally provoked Kant to get involved in the Pantheism Controversy. Kant was not in agreement with Jacobi; and Kant had to make a public statement on this essential point. This lead Kant immediately to write and publish the essay: What does it mean to orient oneself in thinking? And against any link of Kant's philosophy with Spinoza (mentioned by name in this letter).

1786. 11 June. Biester's letter to Kant. "Only you, dearest, most excellent man, I implore you to throw your healing Stone of Minerva on the raving fanatics; reject your initial plan and at least tell the public explicitly and immediately that Herr J. has misunderstood you and that you can never be an ally of the Christian Society for the Advancement of Atheism and Fanaticism." [AK 10:456] "But everyone must be pained by the damage to the good cause and to the person if it can be made to appear that the greatest philosopher of our country and philosophy in general can be accused of supporting dogmatic atheism. This loathsome accusation might then make an impression, an impression which would however be totally weakened if you had previously declared your distance from any connection with this fanatic atheism." [AK 10:457]. This letter must have provoked and disturbed Kant from his slumber.

1786. May. Results of the Jacobian and Mendelsshohnian Philosophy by a Volunteer (Die Resultate der Jacobischen und Mendelssohnschen Philosophie kritisch untersucht von einem Freywilligen). By Wizenmann.

1786. August. Died: Friedrich II was King in Prussia (1740-1786) of the Hohenzollern dynasty. Next was Frederick William II was King of Prussia from 1786 until 1797, then Friedrich William III was King of Prussia from 1797 to 1840. 
1786-1787. August. Letters on the Kantian Philosophy (Briefe über die Kantische Philosophie ). By Karl Leonhard Reinhold. Last installment published in September 1787. These published letters made Kant famous during his lifetime. Reinhold rewrote Kant as doing theology, and hence begun the marketing of Kant's philosophy as theology.

1786. August. Some Remarks on L. H. Jakob's Examination of Mendelssohn's Morgenstunden (Einige Bemerkungen zu Ludwig Heinrich Jakob 's Prüfung der Mendelssohn'schen Morgenstunden). By Kant. (AK 8:149-155).

*** 1786. October. What does it mean to orient oneself in thinking? (Was heißt: sich im Denken orientieren?). By Kant. (AK 8:131-147).

1786. Herder's letter to Gleim. "I am a Spinozist" ("Ich bin ein Spinozist").

1787. February. To professor Kant from the author of the results of Jacobi and Mendelssohn's Philosophy (An den Herrn Professor Kant von dem Verfasser der Resultate der Jacobischen und Mendelssohnschen Philosophie). By Wizenmann. 1787. God: Some Conversations (Gott: einige Gespräche). By Herder.

1787. David Hume on Faith, or Idealism and Realism (David Hume Über den Glauben, oder Idealismus und Realismus). By Jacobi.

1787. Critique of Pure Reason (Kritik der reinen Vernunft) ( $2^{\text {nd }}$ or B-edition). By Kant. (AK 3:1-552).

1788. Critique of Practical Reason (Kritik der practischen Vernunft). By Kant. (AK 5:1-164).

1789. 30 August. Kant's letter to Jacobi. "I have always thought it my duty to show respect for men of talent, science, and justice, no matter how far our opinions may differ. You will, I hope, appraise my essay on orientation, in the Berlinische Monatsschrift, from this perspective. I was requested by various people to cleanse myself of the suspicion of Spinozism, and therefore, contrary to my inclination, I wrote this essay. I hope you will find in it no trace of deviation from the principle I have just affirmed. With inner pain I have read some other attacks upon your views and those of some of your worthy friends, and I have even spoken out against such attacks."[AK 11:76-77].

1789. 16 November. Letter from Jacobi to Kant. "As you are my teacher! As you are a man whom I already admired with a pounding heart when I was young and before 
whom I would now bow with veneration as before a great conqueror and wise lawgiver in the realm of science, were I to say this of you publicly at a time and in circumstances in which no shadow of suspicion could be aroused that I was guilty of self-serving flattery. You yourself, most esteemed Kant, mention your essay "On Orientation," that appeared in the Berliner Monatsschrift; and you mention it in such a way as not only to silence any complaint from my lips but to erase completely and forever even the faintest grievance that might yet be stirred up in my heart. None of your admirers can exceed me in the reverence and affection which I feel for you." [AK 11:102].

1790. Critique of the Power of Judgment (Kritik der Urteilskraft). By Kant ( $2^{\text {nd }}$ edition 1793). (AK 5:165-485).

1790. Essay on Transcendental Philosophy (Versuch über die

Transcendentalphilosophie). By Salomon Maimon. Kant in a letter to Marcus Herz says, "none of my critics understood me and the main questions as well as Herr Maimon does." (AK 11:48 -54). May 26, 1789 lengthy letter to Marcus Herz.

1791. Johann Christian Friedrich Hölderlin (1770-1843) writes in his roommate and friend's yearbook, that is, in Hegel yearbook of 1791 we find an inscription in Greek

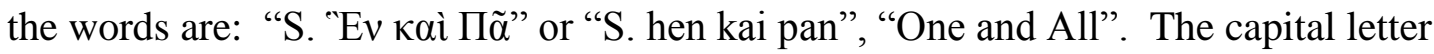
"S" is abbreviation for the word Symbolum (Latin word for symbol). This Greek expression was used by Lessing, and as such was noted by Jacobi. Considered the overall motto for Pantheism.

1793. Religion within the Boundaries of Mere Reason (Religion innerhalb der Grenzen der bloßen Vernunft). By Kant ( $2^{\text {nd }}$ edition 1794). (AK 6:1-202). The actual Preface is dated 6 January 1794; however, Kant had sent the entire book to the theological faculty in late August of 1792.

1794. Spinozism and Brief Presentation of the Spinozistic System (Spinozismus and Kurze Darstellung des Spinozistischen Systems). By Schleiermacher.

1795. 6 January. Schelling's letter to Hegel. "Now I am working on an Ethics à la Spinoza - it shall establish the highest principles of all philosophy, the principles in which the theoretical and practical are united..."

1795. Toward Perpetual Peace: A Philosophical Project (Zum ewigen Frieden. Ein philosophischer Entwurf). By Kant.

1795. 4 February. Schelling's letter to Hegel. "I have in the interim become a Spinozist!" 
1795. 2 July. Fichte's letter to Reinhold about Schelling. "I am most pleased by his inclination towards Spinoza by whose system my system can best be explained." 1795. Metaphysics of Morals (Die Metaphysik der Sitten in zwei Teilen). By Kant.

1796. 23 July. Kant retires from lecturing in the middle of the semester (some reports suggest that Kant had stopped lecturing as early as 1793).

1797. Hyperion or The Hermit in Greece (Hyperion oder Der Eremit in Griechenland). Volume 1 in 1797, Volume 2 in 1799. By Hölderlin.

"To be one with all-this is the life divine, this is man's heaven.

To be one with all that lives, to return in blessed self-forgetfulness into the All of Nature - this is the pinnacle of thoughts and joys, this the sacred mountain peak, the place of eternal rest, where the noonday loses its oppressive heat and the thunder its voice and the boiling sea is as the heaving field of grain."

\section{Atheism dispute (Atheismusstreit) starts.}

1798 to 1799. Atheism dispute (Atheismusstreit). Friedrich Karl Forberg and Fichte. In 1799, Fichte is dismissed from University of Jena, April 1, 1799.

1798. Development of the concept of religion (Entwickelung des Begriffs der Religion). By Friedrich Karl Forberg. Published in the Philosophisches Journal 8, 1, pages 21-46, edited by Fichte.

1798. On the Ground of Our Belief in a Divine World-Governance (Über den Grund unsers Glaubens an eine göttliche Weltregierung). By Fichte.

1798. Autumn. Samuel Taylor Coleridge (1772-1834) and William Wordsworth (1850) travel to Germany. Wordsworth lived for a while in Goslar, Germany.

1798. 18 December. "Saxon requisition letter to the Weimar court" by Frederick Augustus I of Saxony; and "Weimar rescript the University of Jena" by Karl August, Grand Duke of Saxe-Weimar-Eisenach.

1799. 9 January. Appeal to the Public: A writing one is requested to read before confiscating (Appellation an das Publikum). By Fichte.

1799. On Religion: Speeches to its Cultured Despisers (Über die Religion: reden an die Gebildeten unter ihren Verächtern). By Friedrich Schleiermacher (1768-1834).

1799. Open Letter to Fichte (Sendschreiben an Fichte). By Jacobi. Used the term 
nihilism (maybe first usage).

1799. 1 April. Fichte is dismissed from University of Jena. Flees to Berlin.

1799. 7 August. Declaration Regarding Fichte's Wissenschaftslehre (Erklärung in Beziehung auf Fichte's Wissenschaftslehre). By Kant. (AK 12:370-371).

Kant says at the end, "Nevertheless the critical philosophy must remain confident of its irresistible propensity to satisfy the theoretical as well as the moral, practical purposes of reason, confident that no change of opinions, no touching up or reconstruction into some other form, is in store for it; the system of the Critique rests on a fully secured foundation, established forever; it will prove to be indispensable too for the noblest ends of mankind in all future ages." [AK 12: 371].

1799. 6 April. Letter from Reinhold to Fichte.

1799. 5 July. Fichte questioned by police in Berlin.

1800. January. From a Private Letter (Aus einem Privatschreiben). By Fichte.

1800. January. The Vocation of Man (Die Bestimmung des Menschen). By Fichte.

1800. September. Concluding remarks by the Editor. By Fichte.

1802. July. Faith and Knowledge (Glauben und Wissen). By Hegel.

1804. 12 February. Immanuel Kant dies at the age of 79.

1809. Philosophical Inquiries into the Essence of Human Freedom (Philosophische Untersuchungen über das Wesen der menschlichen Freiheit und die damit zusammenhängenden Gegenstände). By Schelling. Short title called "Freiheitsschrift".

1811. On Devine things and their Revelation (Von den Göttlichen Dingen und ihrer Offenbarung). By Jacobi. Attack by Jacobi against Schelling as an atheist.

1812. F.W.J. Schelling's Monument to the writing of the Divine things of the Lord, etc. Mr. Friedrich Heinrich Jacobi: and his made the same accusation of a deliberately deceptive, lying, speaking atheism (F.W.J. Schelling's Denkmal der Schrift von den göttlichen Dingen \&c. des Herrn Friedrich Heinrich Jacobi: und der ihm in derselben gemachten Beschuldigung eines absichtlich täuschenden, Lüge redenden Atheismus). By Schelling. Very successful counterattack by Schelling against Jacobi. Schelling uses this as the Motto of the book, here he quotes Spinoza's remarkable statement, "Oh, what pain! We have now reached the point where those who openly admit that they 
have no idea of God and would not know God in any way, that they cannot help being stupid enough to accuse the philosophers of atheism." At this point, Jacobi was finished philosophically at the hands of Schelling; Jacobi died March 10, 1819.

\section{End of Chronology}




\title{
What is the Purpose of Kant's Orientation Essay?
}

\author{
By
}

\author{
Daniel Fidel Ferrer
}

Indeed, Kant bounced off the Pantheism Controversy after realizing that the Pantheism Controversy was delaying the popular reception of Kant's own critical philosophy. In this way, Kant's attack was a philosophical marketing attack. Kant was not going down in the popular media without a battle for his critical philosophy. What is the place of faith in our onto-theo-logical philosophy? Strictly speaking, Kant wanted to make room for faith (Translator's FN\#1) ---yes, but not much room for faith because the final anvil for the assessment of truth is not revelation, Bible, or faith; but rather, the final philosophical methodology and thinking for truth is reason (ratio). Rationalism is the official answer to the general question - how to orient ourselves in the philosophical world. On this account, Kant's rationalism is a special limited view of rationalism, an empirical, practical, based on freedom; and yet, rationalism and reason is still the chief source and anvil of truth. Thus, it is not Hume's Skepticism, not Mendelssohn's common sense and his form of old rational metaphysics (Kant denied this in the first Critique); certainly not the rational dogmatism of Wolff (in fact, some part of Wolff's philosophy was empiricism). In addition, Kant did not see Jacobi's concepts of revelation or faith as the only acceptable and final answer in metaphysics or theological disputes. Kant has also rejected the empiricism version of John Locke (1632-1704) in the first Critique of Pure Reason in 1781. Kant new brand of philosophy mixes in his concept of freedom and practical morality to find the answer for Kant's critical and enlightenment philosophy. Even though Kant lived in isolation in northern Prussia and he did not travel outside of region; he still wanted to be cosmopolitan in outlook and worldview. Part of his 
family heritage was from Scotland even thought Kant did not know English. Many of his friends did know the English language.

Kant often wanted more from metaphysics, ontology, and philosophy then they could give back to him; hence, his general passage into theology. The elder Kant wants to open up some kind of access and relationship to the supersensible (Übersinnliches). Note: Kant like teaching his theology lectures (4 times, 1774, 1783-84, 1785-86, 1787). According to John Zammito, Kant had made a strong ethical turn and breakthrough in the first four month of 1790. As with most philosophical issues, most especially in Kant's thinking there are many mixed messages, see for example, his essay on the conflict between the philosophy faculty and the theology faculty, written around 1794 [AK 7:17-26]. Indeed, Kant always wanted "more", in fact lots 'more'; but his intellectual honesty was a deep part of his mind set. This warp and weft is basic feature of Kant's philosophical writings. Given the fact of how much of Kant's philosophy has been work on and re-worked (ramifying) these features can be clearly seen in the larger Kantian tradition. Kant had lectured at the University for 41 years and had been active writing philosophy from first philosophical work in 1749 at age 29. Strictly speaking, Kant did not have a complete plan for his system when he first started down the path of philosophical development.

Two letters by Kant give you an idea of his own outlines of his philosophical planning. The first was his plans for the book that became the Critique of Pure Reason (1781).

Kant letter 1772, “... and was then making plans for a work that might perhaps have the title, "The Limits of Sense and Reason." I planned to have it consist of two parts, a theoretical and a practical. The first part would have two sections, (I) general phenomenology and (2) metaphysics, but this only with regard to its nature and method. The second part likewise would have two sections, (1) the universal principles of feeling, taste, and 
sensuous desire and (2) the basic principles of morality." To Marcus Herz, February 21, 1772. (AK 10:129-130).

Second. Kant's overall plan for his system can been seen from this letter. "I shall be glad when I have finished my transcendental philosophy, which is actually a critique of pure reason, as then I can turn to metaphysics, which has only two parts, the metaphysics of nature and the metaphysics of morals, of which I shall present the latter first. I therefore look forward to the future." To Marcus Herz, toward end of 1773. (AK 10:145).

Kant's great system was seen as a work in-progress by contemporaries; and of course this lead to the greatness of Fichte, early Schelling, Hegel, and the later Schelling. Even though the later Schelling's philosophy was not a philosophical system to be followed; but rather, many philosophers critical engaged Schelling and were able to move on their own path as the Hegelian schools started to come apart. Schelling's so called students at the Berlin University in 1841, Lecture Hall No. 6, were Søren Kierkegaard, Mikhail Bakunin, Jacob Burckhardt, Alexander von Humboldt, and Friedrich Engels. Afterwards, they all attacked Schelling. Indirectly, there was also the influence through Engels to Karl Marx (see Marx's letter to Feuerbach, October 3, 1843 against Schelling).

Schelling has his own way of re-thinking philosophical ideas - but not as Kant's critical philosophy. Kant's openness was function of his own mind and his exceptional intellectual honesty. Therefore, Kant's critical philosophy was seen as a starting point and not a completed system or as a finish system, and not having finalized endpoint. Kant at the end of the first Critique of Pure Reason (1781) says, "The critical path alone remains open." (Der kritische Weg ist allein noch offen.) AK 3: 552. In fact, so many philosophical paths were open and taken after Kant, and most of them would not have pleased Kant. Even beyond Kant's public statements against Fichte at the end, in private, he was even more upset over Fichte's 
philosophy and Kant wanted to make sure he was no longer connected to Fichte in the public eye.

Kant wanted followers and so having major parts of the popular philosophical world going off recklessly following Jacob (faith) or Lessing (pantheism) or Mendelssohn (common sense and old rational metaphysics) or Herder and Hamann; so in fact, this did not bode well for the followers or popular option of Kant's own critical philosophy. I think that Kant was partial involved in the Atheism Controversy (1798-1800) and since his named was linked with Fichte (who was dismissed from Jena University in 1799 for Atheism). Fichte was attacked by Jacobi in 1799. The elder Kant had to distance himself as much as possible from Atheism and Fichte. Thus, we see Kant's own attack against Fichte in 1799 (7 August); the title is: Declaration Regarding Fichte's Wissenschaftslehre (Erklärung in Beziehung auf Fichte's Wissenschaftslehre). (AK 12:370-71). Again this is Kant telling his followers - Kant is to be read and one should not take anyone else's version of Kant's philosophy as being correct. As we have seen on this account, Fichte was not the heir apparent after all. In fact, he was pushed out of the fold by Kant.

Kant wrote about Fichte, "Since the reviewer finally maintains that the Critique is not to be taken literally in what it says about sensibility and that anyone who wants to understand the Critique must first master the requisite standpoint (of Beck or of Fichte), because Kant's precise words, like Aristotle's, will destroy the spirit, I therefore declare again that the Critique is to be understood by considering exactly what it says and that it requires only the common standpoint that any mind sufficiency cultivated in such abstract investigations will bring to it." (AK 12: 371). 1799.

Needless to say, Kant was trying to salvage his philosophy and his overall place in history. For Kant what was at stake in the Pantheism Controversy? The short answer: Kant's legacy; and indeed his reputation and the general status of the critical philosophy. Kant did show some hubris about the critical philosophy. Enlightenment (Aufklärung) brings 
back a Kantian version of strong rationalism. Kant's entire conception of "pure reason": transcendental idealism or critical idealism is still encompassed in his overall rationalism.

Conclusion: the purpose of Kant's orientation essay was to re-direct the pantheism controversy back from Spinoza (et alia, and others) and other issues (faith, deism) in the total return to Kant's critical philosophy. It was marketing the critical philosophy to his disciples, supporters, and Kant's followers. Moreover, Kant wanted to bring more intellectuals into the Kantian fold and Kant's view of the critical philosophy. Kant wanted to overcome the other philosophical and theological worldviews at the time. The broad intellectual public had to understand Enlightenment and Kant's critical philosophy.

Translator's Foot Note \#1: Kant wrote in the Preface to the second edition of the Critique of Pure Reason (1787), "Thus, I had to deny knowledge in order to make room for faith." (Ich mußte also das Wissen aufheben, um zum Glauben Platz zu bekommen) (AK 3:19 Kritik der reinen Vernunft).

\section{Selected Bibliography related to Pantheism Controversy}

Enlightenment, Revolution, and Romanticism. By Frederick C. Beiser, Cambridge, Mass.: Harvard University Press, 1992.

The Fate of Reason. By Frederick C. Beiser, Cambridge, Mass.: Harvard University Press, 1987

Spinoza in Germany from 1670 to the Age of Goethe. By David Bell, London: Institute of Germanic Studies, University of London, 1984.

"Fichte, Jacobi and the Atheism Controversy" By C. Bowman, in New Essays on Fichte's Later Jena Wissenschaftslehre, editor 2002. Daniel 
Breazeale and T. Rockmore, Evanston, Illinois: Northwest University Press.

The Genesis of Kant's Critique of Judgment. By John H.

Zammito. University Of Chicago Press; 1st edition (August 1, 1992).

J.G. Fichte and the Atheism Dispute, 1798-1800. Translation and editor, Yolanda Estes and Curtis Bowman. Ashgate Pub. Ltd (2009).

Gotthold Ephraim Lessing: His Life, Works, and Thought. By Hugh Barr Nisbet. Oxford University Press, 2013.

\section{Related Online Resources}

Immanuel Kant (1724-1804) in German http://de.wikipedia.org/wiki/Immanuel_Kant

Immanuel Kant (1724-1804) in English. http://en.wikipedia.org/wiki/Immanuel_Kant http://plato.stanford.edu/entries/kant/ http://www.rep.routledge.com/article/DB047 http://en.wikipedia.org/wiki/Kantian ethics http://plato.stanford.edu/entries/kant-moral

Immanuel Kant's writings in German, AK, volumes 1-23. Elektronische Edition der Gesammelten Werke Immanuel Kants. Druckähnliche Darstellung der Bände 1-23. http://www.korpora.org/Kant/

Hermann Samuel Reimarus [discusses his part in the Fragmentenstreit, Fragment Controversy Author of the Wolfenbütteler Fragmente]. http://en.wikipedia.org/wiki/Hermann_Samuel_Reimarus

G.E. Lessing http://en.wikisource.org/wiki/1911_Encyclopædia_Britannica/Lessing,_Go thold_Ephraim [lengthy discussion] 
G.E. Lessing - modern version

http://en.wikipedia.org/wiki/Gotthold_Ephraim_Lessing

Pantheism controversy

http://en.wikipedia.org/wiki/Pantheism_controversy

Atheism Controversy.

http://en.wikipedia.org/wiki/Atheism_dispute

In German, this page has links to theological controversy, so a starting place on research for these topics.

http://de.wikipedia.org/wiki/Kategorie:Theologische_Kontroverse

General background on rationalism

http://en.wikipedia.org/wiki/Rationalism

The Cambridge Edition of the Works of Immanuel Kant

Series Editors: Allen W. Wood and Paul Guyer.

Titles in English of Kant's writings for this series:

Anthropology, History, and Education

Correspondence

Critique of the Power of Judgment

Critique of Pure Reason

Kant: Natural Science

Lectures on Anthropology

Lectures on Ethics

Lectures on Logic

Lectures on Metaphysics

Notes and Fragments

Opus Postumum

Practical Philosophy

Religion and Rational Theology

Theoretical Philosophy, 1755-1770

Theoretical Philosophy after 1781 


\section{Kant's Note on his Overall Philosophical Position.}

The following note from the elder Kant, I find to be very interesting in the overall understanding of what Kant thought he was actually doing. It is from his later period, and the date is from around 1797.

AK 18:667 to AK 18:668

Notation on timeline for this note: $\omega^{4}: 1796$ - 1798.

Dated time lines of these hand written notes by Erich Adickes and his assistant Friedrich Berger. Adickes came up with 22 distinct time periods in which to sort Kant's hand written notes (Nachla $\beta)$. This note is dated toward the end of Kant's life. Kant died in 1804 at age 79.

From: Notes and Fragments By Kant.

6343. 1796-98 (around May 1797). $L B l$ D 12. P. I.

"The final aim of all metaphysics is to ascend from the cognition of the sensible to that of the supersensible. Now the Critique of Pure Reason proves that this can never be accomplished in a theoretical respect, but it can very well be done in a morally-practical respect by means of the transcendental concept of freedom, which in respect to the theoretical faculty of cognition is [crossed out: fully] transcendent and absolutely inexplicable and indemonstrable, but which with respect to the pure practical faculty (determinable through pure reason alone) has indubitable reality through the categorical imperative. - The reality of the concept of freedom, however, inevitably brings with it the doctrine of the ideality of objects as objects of intuition in space and time. For if these intuitions were not merely subjective forms of sensibility, but rather of objects in themselves, then their practical use, i.e., actions, would depend entirely on the mechanism of nature, and freedom together with its consequence, morality, would be annihilated.

Bottom page. Translator notes: Several disconnected phrases at the end of this note are omitted: "In accordance with the letters, not the intended spirit"; "what the same man says in [this?] connection"; "An insurrection 
of dogmatists in measure.”. Translation by Paul Guyer et al.

Complete German text from online AA. Elektronische Edition der Gesammelten Werke Immanuel Kants.

AK 18:667 to AK 18:668

http://www.korpora.org/Kant/aa18/667.html

6343. $\omega^{4}$ (etwa Mai 1797). L Bl. D 12. S. I, II. R I 217.

$\omega^{4}: 1796-1798$.

Dated time lines of Kant's notes are by Erich Adickes and his assistant Friedrich Berger.

6343. $\omega^{4}$ (etwa Mai 1797). L Bl. D

12. S. I, II. R I 217.

19 S. I:

20 Die Endabsicht aller Metaphysik ist, von der Erkentnis des Sinnlichen

21 zu der des Übersinnlichen aufzusteigen. Die Critik d. r. $\mathrm{V}$. beweiset

22 nun, daß dieses nie in theoretischer, wohl aber in moralisch-practischer Absicht

Zeile: Text:

01 ausgerichtet werden könne vermittelst des transscendentalen Begrifs

02 der Freyheit, der in Absicht Rücksicht auf das theoretische Erkentnisvermögen

03 llig transscendent und allig absolut unerklär 
lich und unerweislich,

04 in Hinsicht aber auf das

reine practische (durch ble reine

05 Vernunft allein bestimbare) Vermögen aber durch den categorisch en Imperativ

06 völlig unbezweifelte Realität hat. - Die Realität des Freyheitsbegrifs

07 aber zieht unvermeidlicherweise die Lehre von der Idealität der

08 Gegenstände sorn sie als Objecte ihrer der Anschauung im Raume und

09 der Zeit nach sich. Denn wären diese Anschauungen nicht blos su bjective

10 Formen der Sinnlichkeit, sondern der Gegenstände an sich, so würde der

11 practische Gebrauch derselben, d. i. die Handlungen würden der schlechterdings

12 nur von den Mechanism der Natur abhängen, und Freyheit sammt

13 ( ${ }^{\mathrm{g}}$ ihrer Folge ) der Moralität wäre vernichtet.

14 S. II:

15 Dem Buchstaben nach, nicht dem Vermeynten Geist.

16 In umgekehrter Richtung:

17 was eben derselbe Mann im Zusammenhange sagt.

18 Ein Aufstand der Dogmatiker in Masse. 


\section{Dedication and Acknowledgements.}

To my many outstanding conversations with Harvey Williams about Kant staring in 1970s. A lunch and an afternoon walk with Professor Dr. Lewis White Beck. My personal return to Kant recently, has been via my Kantian questions in e-mails with Professor Dr. A. K. Rai (publishes under the name of Dr. Arvind Kumar Rai) of Banaras Hindu University's Philosophy Department (where I went to graduate school). Professor Dr. A. K. Rai was teaching a class on Kant's Prolegomena to any Future Metaphysics that will be able to come forward as a Science (1783); and I thought it was essential to return to Kant. How come we are always returning to Kant and not just "remaining" with Kant?

As a famous motto calls us back to Kant, Otto Liebmann's writes in 1865 :

\section{"Also muss auf Kant zurückgegangen werden." "Therefore, must return to Kant."}

I would also like to acknowledge the general philosophical encouragement from Professor Dr. Dr. Holger Zaborowski. My long time friend and philosophical questioner: Professor Richard Pulaski; including recent conversations on the purpose of Kant's overall project. A single great question is worth more than a1000 answers.

I alone have done this translation. All the errors our mine alone.

Family members. I have a personal family connection in 
Wolfenbüttel during the time of G. E. Lessing. My family members: Heinrich Wilhelm Kuhn (05.01.1752 - 05.01.1818) wife Dorothe (nee Bleibtreu) Kuhn (14.03.1758 - 29.08.1831); Julius Wilhelm Kuhn (09.06.1781 - 08.08.1850) Pastor in Wolfenbüttel, old Prussia, Germany. Deutschland. Julius Kuhn (Verden, Germany, 1847-1890). Ernesto B. Ferrer, jr, Louise (born Reavis) Ferrer, Joseph R. Ferrer, Alice Amanda Ferrer, Dolores Juanita Ferrer, Shobha Ferrer, Vandana Kiran Young, Scott Young; Kaiden Curtis Young, Maliha Kiran Young, Zoe Ashlynn Young. Ashmita Rita (Marguerita) Ferrer, Marguerita Ruth Ferrer, Ernesto Jo Ferrer, Laurie and Daniel Large. Rafael Ferrer, Loren Fidel Ferrer, and Cory Ferrer. My family in Germany, Deutschland particularly: Dr. Jan-Peter Wülbern (his Almuth) and Peer Kuhn and families.

Friends in particular in Chicago and Khambholaj, Natu Patel, and Patel families. Kamlesh Patel and family. Dr. P. R. Gupta (BHU) and families.

\section{Appendix A.}

First page of Immanuel Kant's Text of 1786 (October).

Berlinische Monatsschrift 2, 1786 October, pages 304-330.

Berlinische Monatsschrift

(einschließlich ihrer Nachfolger Berlinische Blätter und Neue Berlinische Monatsschrift). Hrsg.: J. E. Biester, F. Gedike, Berlin, Germany.

Online

Berlinische Monatschrift. 1783-1811 (full scan of text for these years). http://www.ub.uni-bielefeld.de/diglib/aufkl/berlmon/berlmon.htm 


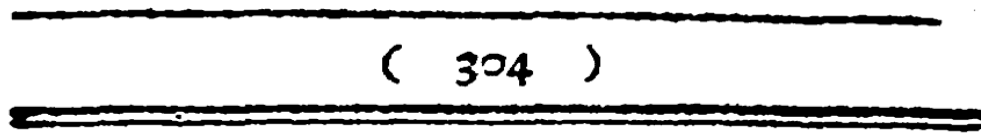

z.

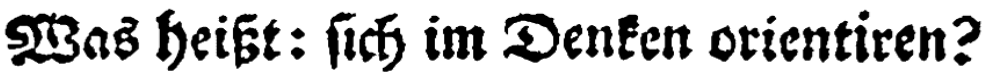

SWB

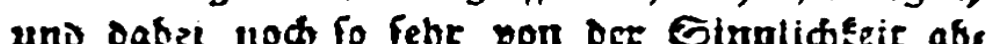
ftrablten, is bìngen threat cod nod tmmer bilo= lid)e $\mathfrak{B}$ orfellungen an, beren etgentlidie bejims mung es iff, fte, oie fonit nidyt yon det Erfalgeung

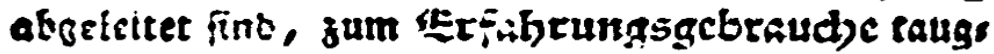
(id) j" maden. Danu wie wollten wit aud) unies ren Begrtfien Einn unb Beocutung verjonafien,

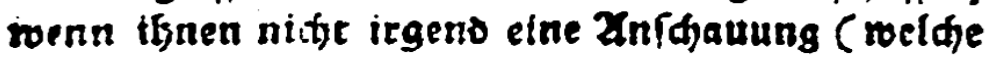

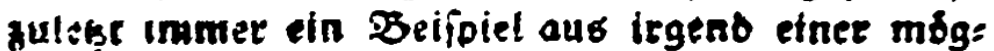
lid,ar Exfabrung (cia mü) untergelegt rourte?

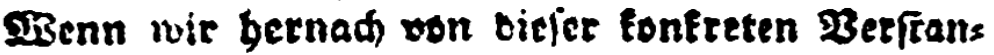
Deshandlang die Betmifhang bes 23 lloes, juerf - oer zufalligen sán rmebmang Durd) Binne, Dann To gar oie reine finnithe Znfdautng überbaupt, reglaffea: fo bleibt jener reine serfandesbegrif ubrig, orfien Uimfang nun exweitert $t_{\mathfrak{t}}$, und eine Tieget ocs Denfens überhaupe entbalt. Xuf iolde Iscife iff feloft ote alljimeine Rogif au Stande ge: fommen; uni mandie bencififiche Dretbode in benten liegt in sem Erinbrungegebrautie unferes Berficandes und ser Bernunft vielletdit nod ver: borgen, weldie, wonn mit fie befutiam aus jerta Crfabrung barausjugtiban gefínten, dic pgilos

fopfite

Caption: this is the first page of Immanuel Kant's article in German from the original publication of 1786. 


\section{Index}

\section{A}

AA, 22, 25, 46

abbreviation, 34

aber, 21, 46-47

Aberglauben, 21

abgenötigte, 18

abhängen, 47

abilities, 14

ability, 7,18

able, 8-9, 20, 27, 31, 40, 48

about, 3, 6-7, 9-11, 14, 16, 19, 26, 30-31, 35, 41, 48

Absicht, 46

absichtlich, 36

absolut, 46

absolutely, 10, 45

Abstract, 24

abstract, 5, 24, 41

abstrakte, 24

abuse, 16

academic, 23

Academy, 25

Accept, 17

accept, 9-10, 20

acceptable, 9-10, 38

accepts, 16

access, 18, 20, 39

accident, 20

accidental, 10

accompanied, 15

accompany, 11

accomplished, 45 accord, 27

accordance, 45

According, 39

according, 8-9, 14, 24

Accordingly, 4

account, 32, 38, 41

accounts, 11

accuracy, 15

accurate, 7

accusation, 32, 36

accuse, 37

accused, 32

accustom, 21

achieve, 24

acknowledge, 48

Acknowledgements, 2, 48

action, 5

actions, 45

active, 39

acts, 19

actual, 9, 23, 34

actually, 3, 40, 45

ad, 6

add, 23

added, 3, 23

addition, 12, 17, 23, 38

adequately, 13-14

Adickes, 45-46

admirable, 10

admire, 14

admired, 33

admirers, 34

admissibility, 11

admission, 19 
admit, 36

admitted, 18

admixture, 5, 14

adopted, 16

advance, 5, 19

Advancement, 32

Adverse, 17

Advertiser, 31

Aenesidemus, 29

affection, 32, 34

affirmed, 33

after, 9, 13-14, 17, 27, 38, 40-41, 44

afternoon, 48

Afterwards, 40

afterwards, 5, 13

Again, 41

again, 18, 41

Against, 28

against, 3-4, 7, 14, 27-28, 31-33, 36, 40-41

Age, 42

age, 30, 36, 39, 45

agent, 11

ages, 36

agility, 11

agree, 13

agreed, 8

agreement, 32

ahead, 3, 10

aim, 45

Aims, 30

AK, 22, 25, 30-34, 36, 39-43, 45-46

al, 46

Alexander, 29, 40

alia, 42

Alice, 49

align, 11

aligned, 9

All, 2, 12, 22-23, 30-31, 34-35, 48

all, 4, 7-16, 18-20, 23, 27, 31, 34-36, 40-41, 45

alleged, 6

allein, 40, 47

Allen, 26, 44

aller, 46

allerrealesten, 18

Allgemeine, 31

allowed, 11, 20

ally, 32

almost, 14, 31

Almuth, 49

alone, 9, 11-13, 15-16, 40, 45, 48

already, 10-11, 33

als, 8, 31, 47

Also, 26, 48 also, 5, 7, 9-10, 14-15, 17-20, 28, 38, 40, 42, 48

Alternatively, 4

although, 4, 6-8, 12, 20

always, 4-5, 12, 16, 18, 27, 33, 39, 48

am, 8, 23, 33-35

Amanda, 49

ambiguity, 6

ambiguous, 12

among, 7-8, 16

An, 27, 31, 33, 45

an, 4, 6, 9-15, 18, 20-21, 23-24, 27, 30-32, 34-36, 38-39, 47-48

analogy, 8

And, 6, 11, 14, 17, 32

and, 1-21, 23-46, 48-49

Anfangsgründe, 32

Anmaßung, 20

Annehmung, 9-10

annihilated, 45

Anonymous, 30

anonymously, 30-31

another, 14-15, 20

Anschauung, 47

Anschauungen, 47

Answer, 3, 26

answer, 23, 38, 41

answers, 48

Anthropology, 44

anvil, 38

anxious, 15

any, 4-5, 7, 9, 11-16, 20, 31-32, 34, 37, 41, 48

anyone, 23, 41

anything, 9

Anzeigen, 31

Apart, 31

apart, 40

apartment, 30

apparent, 41

Appeal, 35

appear, 32

appearance, 13

appeared, 34

appears, 24

Appellation, 35

Appendix, 2, 49

applied, 10, 19

appraise, 33

appreciate, 23

approach, 23

approaches, 24

appropriate, 12-13, 17

April, 24, 32, 35-36

arbitrary, 8 
are, $3,5-7,9-12,14-15,18,20,23,27,31,33-34,39$, $45-46,48$

argument, 6, 15

argumentum, 6

arise, 16

Aristotle, 41

around, 24, 39, 45

aroused, 34

arrives, 30

arrogance, 15

Art, 13

article, 51

Arvind, 48

As, $33,39,41,48$

as, 4-6, 8-20, 23, 27-28, 31, 33-36, 38, 40-41, 45, 48

ascend, 45

Ashgate, 43

Ashlynn, 49

Ashmita, 49

ask, 20

assent, 12, 14, 18

assert, 20

assertion, 10, 27

assessing, 12

assessment, 38

assets, 6, 8, 16, 18-19

assistant, 45-46

assume, 9-10, 21

assumed, 21

astronomer, 7

At, 26, 37

at, $4,7,9-11,13,16,18,23,27-28,30-32,34,36-37$, $39-42,45$

Atheism, 2-3, 32, 35, 41-44

atheism, 4, 14, 28, 32, 36-37

Atheismus, 36

Atheismusstreit, 35

atheist, 4, 30, 36

Atheisterei, 14

attaches, 8

Attack, 36

attack, 38, 41

attacked, 28, 30, 40-41

attacking, 6, 24

attacks, 7, 14, 33

attempts, 11

attitudes, 14

Attribution, 2, 22

auch, 17

auf, 36, 41, 46-48

aufheben, 42

Aufklärung, 3, 41

Aufstand, 47 auftreten, 31

aufzuklären, 21

aufzusteigen, 46

August, 27, 29-30, 32-36, 41, 43

Augustus, 35

Auktorität, 13

Aus, 36

ausgerichtet, 46

Author, 43

author, $6,10,12,33$

authorities, 16

authority, 12-13, 16

authorized, 14

authors, 2, 20, 29

autocracy, 16

Autumn, 35

available, 23

Awakening, 28

awareness, 12

B

back, 4, 24, 39, 42, 48

backdrop, 4

Background, 2

background, 23-25, 44

bad, 16

Bakunin, 40

Banaras, 48

banish, 15

Barr, 43

barriers, 8,18

Barry, 26

Baruch, 29

based, 6, 13, 38

basic, $6,12-13,21,27,31,39-40$

basically, 18

battle, 38

Baumgarten, 29

be, 4-21, 24, 27, 30-32, 34-36, 38-41, 45, 48

beautiful, 18

became, 39

Because, 10, 14, 16

because, 7-13, 15-16, 19-20, 38, 41

Beck, 29, 41, 48

become, 7, 15, 34

bedienen, 17

Bedürfnisses, 8 
been, 11-12, 17, 20, 39-40, 48

before, 4, 7-8, 11, 13, 20, 33-35

begin, 15, 21

Begriff, 20

Begriffen, 5

Begriffs, 35

Begrifs, 46

begun, 33

behaving, 16

behendeste, 16

Behuf, 7, 9, 18

bei, 18

Being, 11-12, 14

being, 9-10, 13-14, 18, 20, 31, 37, 41

beings, 9

Beiser, 42

bekommen, 42

Belief, 35

belief, 12-14, 16, 28

believe, $4,12,16$

believed, 12

Bell, 42

belong, 24

belongs, 24

Bemerkungen, 33

ben, 29

Berger, 45-46

Berlin, 32, 36, 40, 49

Berliner, 32, 34

Berlinische, 25, 33, 49

Beschuldigung, 36

best, 16-17, 27, 35

bestimbare, 47

bestimmen, 18

Bestimmung, 36

better, 3,23

between, 3, 6, 27, 39

bewandt, 10, 18-19

beweiset, 46

beyond, 8, 20, 24, 27, 40

Beziehung, 36, 41

BHU, 49

Bible, 23, 38

Bibliography, 2, 42

Bibliothek, 30-31

Biester, 29, 32, 49

big, 13

biggest, 15

bin, 33

birth, 2, 29, 31

bjective, 47

$\mathrm{Bl}, 46$

blame, 15
Bleibtreu, 49

Blessed, 6

blessed, 35

blind, 31

blo, 47

blos, 47

bloßen, 34

Blätter, 49

board, 20

bode, 41

body, 31

boiling, 35

bold, 16

boldly, 16

book, 30-31, 34, 36, 39

books, 27

Born, 1

born, 49

both, 4, 21, 27

Bottom, 45

bounced, 38

Bound, 30

Boundaries, 34

boundaries, 20

boundary, 19

bourgeois, 15

bow, 15, 34

Bowman, 42-43

brand, 38

break, 16

breakfast, 30

breakthrough, 39

Breazeale, 43

Breslau, 17

Brief, 34

Briefe, 33

Briefen, 31

bring, 4, 6, 9, 16, 20, 41-42

brings, 41,45

Britannica, 43

broad, 42

Brunswick, 30

Buchstaben, 47

building, 27

Burckhardt, 40

burdens, 15

business, 6,8

But, 6-10, 12, 14, 21, 27, 31-32

but, 4-16, 18-20, 23-24, 27, 34, 38-40, 45

BY, 2, 22

By, 1-3, 9, 23, 25-26, 30-36, 38, 42-43, 45

by, 1-2, 5-9, 11-21, 23, 26-30, 32-36, 39-41, 45-46

Bände, 43 


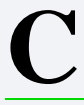

call, $7,13,16$

called, 6, 20, 30-31, 36, 40

calls, 16, 48

Cambridge, 26, 42, 44

came, 45

can, 3, 6-10, 12-16, 18-21, 23-24, 27, 32, 34-35, 39-40, 45

cannot, 8-10, 13, 16, 20, 27, 37

capital, 30, 34

Caption, 51

careful, 17

carefully, 27

carried, 20

Cartesian, 18

case, 25

casual, 11

categorical, 45

categorically, 11

categorisch, 47

caught, 20, 32

cause, 8,32

caused, 19, 32

causes, 9-10, 16

Caveats, 23

CCPL, 2, 22

central, 4

certain, 6, 8, 11, 13-14, 19-20

certainly, $3,17,38$

certificates, 12, 16

challenging, 3

chance, 9

change, $7,11,19,36$

changed, 12

characteristic, 13

characteristics, 27

charmed, 16

check, 13

Chicago, 43, 49

chief, 38

choice, 11

Christian, 29, 32, 34

Chronology, 2, 29, 37

chronology, 2-3

circle, 7

circumstances, 34

citation, 25

cited, 11

citizens, 15 city, 12,31

civic, 15

civil, 16

claim, 4, 23

claimed, 6

class, 48

cleaning, 6

cleanse, 33

clear, 13

clearly, 7, 39

close, $4,10,14$

closer, 3, 23, 27

coexist, 14

cognition, 45

coherent, 14

coincide, 31

coincidence, 6

cold, 32

Coleridge, 35

collection, 25

come, 5, 7, 13, 16, 31, 40, 48

comes, 9

command, 16

Commercial, 2, 22

Common, 28

common, 4, 6-7, 11, 13, 16, 38, 41

Commons, 2, 22

community, 6,15

company, 6

compass, 13

compelled, 10, 18

competes, 19

complaint, 34

Complete, 46

complete, $7,18,39$

completed, 40

completely, 19, 34

complex, 27

comprehensive, 27

compulsion, 15

conceded, 11

concentration, 31

concept, 5, 7-11, 13-14, 20, 27, 35, 38, 45

conception, 8,42

conceptions, 20

concepts, 5, 9, 20, 38

concern, 14

Concerning, 27

concerning, 8

Concluding, 36

Conclusion, 42

conclusions, 6

concrete, 5 
condition, 9-10, 16

conditionally, 10

conditions, 18, 20

confession, 6, 11

confidence, 16

confident, 36

confirmed, 14

confiscating, 35

conflict, 39

confusion, 16

connect, 10

connected, 41

connection, 32, 45, 48

conqueror, 34

conscience, 15

consciousness, 12, 19

consequence, 45

consequently, 9, 19

consider, 4, 9, 18

consideration, 12

Considered, 34

considered, 4, 30

considering, 7, 41

considers, 8

consist, 39

consistent, 18

consists, 20

constellations, 7

contact, 8

contained, 12

contemporaries, 40

Contents, 2

Context, 2-3

context, 3-4, 26-27

contingency, 10

continue, 9, 15

Contra, 28

contra, 4

contradict, 13

contradiction, 20

contradictions, 6, 9

contradictory, 20

contrary, 13, 19, 33

contrast, 6, 12-13, 20

controversial, 4, 30

controversies, 3

Controversy, 2-4, 27, 29-30, 32, 38, 41-44

controversy, 4, 14, 23, 32, 42, 44

convenience, 10

conversational, 23

Conversations, 30, 33

conversations, 48

conviction, 13 convinced, 14

copy, 30

Copyright, 2

copyright, 22

core, 30

corollary, 11

correct, 41

Correspondence, 44

Cory, 49

cosmopolitan, 38

could, 5, 8-9, 11, 13-15, 19, 34, 39

counsel, 15

counseled, 19

counterattack, 36

countering, 28

country, 32

course, 4, 6, 15-16, 23, 40

court, 35

created, 7, 14

Creative, 2, 22

creatures, 14

credible, 17

creeds, 15

critical, 3-4, 20, 36, 38, 40-42

criticism, 19-20

critics, 34

Critik, 46

Critique, 4, 19-20, 23-24, 28, 30-31, 33-34, 36, 38-45

critique, 40

crossed, 45

Crusade, 30

crypto, 4

cultivated, 41

cultural, 3

Cultured, 35

curiosity, 9

currents, 27

Curtis, 43, 49

cuts, 19

\section{D}

dadurch, 17

damage, 32

damit, 36

danger, 6

Daniel, 1-3, 22-23, 26, 29, 38, 42, 49

dare, 9, 11 
dark, 8

Darstellung, 34, 43

Das, 24

das, $8,10,31,35-36,42,46-47$

Dasein, 31

Data, 12

data, 12

date, 45

Dated, 45-46

dated, 34, 45

Datis, 7

Daughter, 29

David, 33, 42

day, 7

daydreaming, 9

days, 24

dazu, 17

daß, 46

dearest, 32

death, 4, 12, 32

December, 31-32, 35

deception, 32

deceptive, 36

decided, 19

Declaration, 36, 41

declare, 41

declared, 15, 32

dedicate, 4

Dedication, 2, 48

deduce, 11

deep, 39

defense, 6

definite, 20

Definitely, 4

definitely, 7

definition, 27

definitions, 19

degenerate, 16

degree, 13

Deism, 28

deism, 3-4, 42

Deist, 30

deity, 13

delaying, 38

deliberately, 16, 36

deliver, 13

Dem, 47

dem, 17, 30, 33, 47

demonstrate, 11-12

demonstration, $6,16,18$

den, 17, 31, 33, 35-36, 47

denial, 4, 28

denied, 19, 27, 38 denies, 16-17

Denken, 1-2, 18, 22, 24-25, 33

Denkmal, 36

Denn, 47

denn, 21

deny, 42

Department, 48

depend, 23, 45

dependent, 11

depends, 27

Der, 35, 40

der, 8, 13, 17-18, 25, 30, 32-36, 42-43, 46-47

derived, 5, 11, 18

derselbe, 47

derselben, 18, 36, 47

des, 8, 11, 31, 34-36, 46-47

Descartes, 28-29

description, 7

designate, 27

designed, 20

desire, 19, 40

desk, 27

Despisers, 35

destiny, 5

destroy, 20, 41

destroying, 17

detail, 27

determinable, 45

determination, 8, 13, 18, 20

determine, 7-8

determined, 8, 13, 18-19

determining, 8,11

dethronement, 6

detriment, 18

Deutsche, 31

Deutschland, 49

developed, 27

Development, 35

development, 23, 39

deviation, 33

Devine, 36

di, 26

dialectic, 20

did, 3-4, 13, 23-24, 38-39, 41

Die, 32, 35-36, 46-47

die, 19-20, 31, 33-36, 47

Died, 32

died, 1, 30, 32, 37, 45

dies, 36

diese, 47

dieser, 17

dieses, 17, 46

differ, 31, 33 
difference, 7-8

different, 12, 27

difficult, 23

Dingen, 36

Direct, 4

direct, 42

direction, 4, 7

disadvantage, 6

disagreement, 31

disappear, 6, 21

disaster, 17

discernment, 7

Disciples, 30

disciples, 42

discipline, 19

disconnected, 45

discovered, 13, 27

discusses, 43

discussion, 43

discussions, 30-31

dismissed, 35-36, 41

disorder, 16

disorient, 7

disposed, 17

disprove, 19

Dispute, 43

dispute, 6, 14, 35

disputed, 14

disputes, 38

dissolve, 20

distance, 32, 41

distinct, 45

distinction, 7, 14, 18

distinguish, 7-8

distinguished, 13

distinguishing, 8

distress, 18

distributed, 10

distribution, 2, 22

disturbed, 32

diversity, 18

divide, 7

Divine, 35-36

divine, 35

divinity, 14

Do, 23-24

do, 8-9, 13-16, 18, 21, 23, 31

doctrine, $17,31,45$

doctrines, 4

documents, 8

Does, 1-2

does, 3-5, 10, 15, 19, 23, 25, 30, 32-34

dogmatic, 16, 19-20, 32
Dogmatiker, 47

Dogmatism, 28

dogmatism, 19, 28, 38

dogmatists, 46

dogmatizing, 18

doing, 14, 33, 45

Dolores, 49

dominant, 24

done, 45, 48

Dorothe, 49

doubt, 14, 18

down, 38-39

Dr, 48-49

Draft, 31

Drang, 3, 28

drawn, 4

drew, 16

drive, 31

driving, 11, 16

Druckähnliche, 43

due, 9-10

Duke, 30, 35

durch, 47

During, 3

during, 23, 30, 33, 49

dustbins, 24

duty, 16, 33

dynasty, 32

$\mathbf{E}$

each, 7, 16, 18, 21

Earlier, 2

earlier, 3, 26

earliest, 7

early, 15, 21, 35, 40

earned, 19

earth, 17

easily, 8, 11, 21

east, 7

easy, 3, 23

eben, 47

Eberhard, 27

ed, 26

edited, 26, 31, 35

Edition, 25, 43-44, 46

edition, 30, 33-34, 42-43

Editor, 36 
editor, 32, 42-43

Editors, 44

Education, 44

education, 21

effect, 9

effects, 12

effusive, 6

eigenen, 8

Ein, 21, 34, 47

ein, 13, 24, 33

einbüßen, 17

eine, 24,35

einem, 18, 32, 36

einer, 31

eines, 36

Eingeschränkten, 10

Einige, 33

einige, 33

einschließlich, 49

Eisenach, 35

either, 6, 12

elder, 39, 41, 45

Eleatic, 20

Elektronische, 25, 43, 46

Elise, 29

else, 11, 13, 16, 27, 41

elsewhere, 3

emphatic, 16

empirical, 38

empiricism, 38

employment, 9

en, 47

encompassed, 42

encounters, 10

encouragement, 48

End, 37

end, 14, 36, 40, 45

Endabsicht, 46

endpoint, 40

ends, 36

enemy, 18

engaged, 24, 40

Engels, 40

English, 1-3, 5, 21, 23, 26, 39, 43-44

enhanced, 7

enjoins, 14

enlighten, 21

enlightened, 20

Enlightenment, 3, 20-21, 26, 41-42

enlightenment, 16, 38

enough, 9, 13, 16, 37

Enquiry, 27

entangled, 20, 27 entered, 11

enthusianism, 16, 21, 28

enthusiasm, 6, 20

entire, 16, 27, 34, 42

entirely, 13, 19, 45

entitled, 6

Entwickelung, 35

Entwurf, 34

Enweckung, 28

Ephraim, 29, 43

epithets, 27

equal, 13

era, 21

eradicate, 20

erase, 34

Eremit, 35

Erich, 29, 32, 45-46

Erkentnis, 46

Erkentnisvermögen, 46

Erklärung, 36, 41

Ernesto, 49

Ernst, 29

error, 8

errors, 8,48

erschweren, 21

Erziehungsart, 21

es, 21

especially, 6, 28, 39

Essay, 2, 34, 38

essay, 2-3, 19, 23-26, 32-34, 39, 42

Essays, 42

essays, 2-3

Essence, 27, 36

essence, 9, 13

essential, 27, 32, 48

establish, 21, 34

established, 36

establishment, 14

esteemed, 34

Estes, 43

et, 42,46

etc, $2,12,36$

eternal, 35

ethical, 39

Ethics, 34, 44

etwa, 46

Evanston, 43

Even, 20, 27, 38, 40

even, 5-10, 12-17, 19, 23, 33-34, 39-40

events, 16

Every, 12

every, 13

everyone, 14, 16, 31-32 
everything, 10-11, 14, 16, 27

everywhere, 10-11, 14, 20

evidence, 6, 18-19

evil, 19

evolutions, 18

ewigen, 34

exactly, 41

Examination, 33

examination, 15,17

example, 5, 12, 27, 39

examples, 18

exceed, 34

excellent, 26, 32

except, 7

exceptional, 40

exchanged, 4

exemption, 15

exercise, 6-7

exist, 7

existed, 11

existence, 5, 9-14, 18, 31

exists, 12,20

expand, 7-9, 12, 19

expatriate, 24

expect, 12

expectations, 16

expediency, 10

experience, 5, 8-9, 12, 14, 18

explain, 10,12

explained, 35

explanation, 13

explicitly, 6,32

expose, 32

express, 31

expression, 12, 28, 30, 34

extend, 8

extended, 5, 8, 14

external, 13, 15, 21

extraordinary, 27

eye, 7,41
Faith, 28, 33, 36

faith, 3-4, 6, 12-14, 16, 19, 28, 38, 41-42

faithful, 32

falling, 10

familiar, 7-8

families, 49

Family, 48

family, 39, 48-49

famous, 23, 30, 33, 48

famously, 30

fanatic, 32

Fanaticism, 32

fanaticism, 14, 16, 19, 21, 28, 32

fanatics, 32

fantasies, 9

Far, 10

far, $4,6,10,13,21,33$

fatal, 6

fatalism, 4, 28

Fate, 42

favorable, 6, 16

fear, 15

fears, 4

feasible, 21

feast, 24

feature, 39

features, 39

February, 30, 33-34, 36, 40

Feder, 27, 31

Federation, 31

feel, 7, 14, 19, 34

feeling, 7-8, 13, 19, 39

feels, 7, 9-10

feet, 31

felt, 11

fern, 47

Ferrer, 1-3, 22-23, 26, 38, 49

Fest, 24

Feuerbach, 40

few, 23

Fichte, 29, 35-36, 40-43

Fidel, 1-3, 22-23, 26, 38, 49

field, $9,13,19,35$

fill, 9

Final, 21-22

final, 9, 38, 45

finalized, 40

Finally, 8, 17

finally, 4, 12, 32, 41

find, 7, 11, 18-21, 33-34, 38, 45

finden, 21

finish, 40

finished, 37, 40

fact, 4, 6, 8, 16, 23, 38-41

Facta, 16-17

faculty, 20, 34, 39, 45

faintest, 34 
First, 16, 49

first, 2, 4-6, 9-11, 13-16, 24, 28, 30-31, 36, 38-41, 51

fit, 3,5

fix, 3,23

flattery, 34

Flees, 36

Flügel, 19

FN, 38

fold, $41-42$

Folge, 47

follow, 21, 31

followed, 23, 40

follower, 27, 31

followers, 41-42

Following, 30

following, $27,41,45$

follows, 16, 27

Foot, 42

Footnote, 4, 17-20

footnote, $6,8,10-11,13-14,17$

footnotes, 17

For, 7, 9-10, 18-19, 21, 27, 41, 45

for, 2-4, 6-21, 23-25, 27-28, 30-36, 38-42, 44-45, 49

Forberg, 29, 35

force, 11,15

forced, 16

forces, 16

forever, 20, 34, 36

forfeited, 15

forget, 11

forgetfulness, 35

forgot, 32

form, $16,36,38$

format, 25

Formen, 47

former, 11, 28

forming, 6

forms, 45

forward, 10, 31, 40, 48

found, $6,8,13,18-21$

foundation, 10, 13, 18, 36

Foundations, 32

foundations, 18-19

founded, 12

four, 7, 39

Fragment, 30, 43

Fragmente, 43

Fragmentenstreit, 30, 43

Fragments, 2-3, 30, 44-45

Frederick, 32, 35, 42

Free, 2, 22

free, 9, 14, 16, 18-19, 28

Freedom, 27, 36 freedom, 4, 10, 14-17, 28, 38, 45

Freigeisterei, 16

Freiheit, 17, 36

Freiheitsschrift, 36

frenzy, 24

frequent, 7

Freunde, 31

Freyheit, 46-47

Freyheitsbegrifs, 47

Freywilligen, 32

Frieden, 34

Friedrich, 3, 29-30, 32, 34-36, 40, 45-46

friend, 28, 34, 48

Friends, 31, 49

friends, 6, 17, 32-33, 39

From, 3, 25, 31, 36, 45

from, 2 , 4-5, 7-8, 10-19, 21, 24, 26-27, 31-36, 39-42, $45-46,48,51$

frugal, 10

full, 18, 25, 49

fully, 11, 13, 36, 45

function, 40

funeral, 12

further, 19

Future, 31, 48

future, 14, 36, 40

für, 24

Fürwahrhalten, 18

G

game, 15

Garve, 31

gate, 14

Gaukelwerk, 32

Gebildeten, 35

Gebrauch, 47

Gedike, 49

Gefühl, 7-8

Gegenstände, 9, 36, 47

Geist, 47

Gelehrten, 31

gemachten, 36

gemeine, 11

gemeinet, 12

General, 2, 22, 25, 31, 44

general, 5, 18, 21, 27, 32, 38-39, 41, 48

generally, 23 
Genesis, 43

genesis, 23

genius, 14-16

gently, 5

geographical, 7

geographically, 7

Georg, 27, 29

George, 26

German, 2-3, 12, 17, 23, 25-28, 31, 43-44, 46, 51

Germanic, 42

Germany, 1, 3-4, 23, 30, 35, 42, 49

Gesammelten, 25, 43, 46

Geschichte, 30

Gesetz, 19

gesetzmäßig, 17

gesinnt, 17

Gespräche, 33

gesunde, 6

get, 14, 27, 32

getting, 24

gewesen, 17

Giovanni, 26

give, $3,5,8,11-12,14,18,27,39$

Given, 23, 39

given, $7,12-13,18$

gives, 15

glad, 40

Glaube, 28

Glauben, 14, 33, 36, 42

Glaubens, 6, 35

Gleim, 29, 33

Go, 24, 43

go, 3-4, 13, 19, 24

God, 4, 10, 13-14, 18-19, 28, 31, 33, 37

goes, 20

Goethe, 3, 31, 42

Goeze, 29-30

going, 8, 20, 38, 41

good, 10-11, 16-17, 24, 32

Goslar, 35

Gott, 33

Gottes, 31

Gottfried, 29

Gottheit, 13

Gotthold, 29, 43

Gottlieb, 29

Gottlob, 29

Governance, 35

graced, 16

grade, 10

gradual, 12

graduate, 48

grafted, 6 grain, 35

Grand, 35

grant, 14

granted, 14

great, 10, 12, 16, 18, 34, 40, 48

greater, 23, 27

greatest, 10, 16, 32

greatness, 40

Greece, 35

Greek, 30, 34

green, 2, 23

Grenzen, 34

Griechenland, 35

grievance, 34

grill, 20

Grillen, 20

Ground, 35

ground, 7, 11, 18-19

grounds, 12,17

Grund, 35

Grunde, 18

Gründe, 19

Gründen, 18

Gründsätze, 19

guardians, 15

guess, 8

guidance, 8

guide, 8,13

guided, 8, 20

guideline, 13

guideposts, 27

guiding, 4

guilty, 34

Gupta, 49

guten, 24

Guyer, 44, 46

Göttingen, 31

Göttischen, 31

göttliche, 35

Göttlichen, 36

göttlichen, 36 habitual, 11

had, $4,8,13,20,27,32,34-35,39,41-42$

Hall, 40

Hals, 17 
Hamann, 3, 27-29, 41

hand, 6-7, 12, 15, 45

handle, 23

Handlungen, 47

hands, 7, 37

hanging, 5

Hans, 26

happen, 9

happened, 6

happens, 8,20

happiness, 10

hard, 19

hardly, 32

hardship, 24

harmful, 9

Harvard, 42

Harvey, 48

has, 5, 14, 16, 20-21, 23, 27, 32, 38-40, 44-45, 48

hat, 47

have, 3-4, 6, 8-11, 14, 16-19, 23, 31-34, 36-37, 39-41, 48

having, 16, 40-41

He, 31

he, $6-8,11,13-14,16,18-19,27,32,36,38-41,45$

head, 31

healing, 32

healthy, 6

heart, 16, 33-34

heat, 35

heaven, 35

heaving, 35

Hegel, 29, 34, 36, 40

Hegelian, 40

Heidegger, 24

Heinrich, 27, 29, 33, 36, 49

heir, 41

heißt, 1-2, 18, 22, 25, 33

held, 11-12, 18, 30

help, 6-7, 23, 27, 37

helpful, 7

helps, 8

hen, 30,34

hence, 18, 33, 39

Herder, 3, 27-29, 33, 41

Here, 16

here, 3, 6, 8, 11-12, 36

hereby, 19

herein, 11, 19

heritage, 39

Hermann, 29-30, 43

Hermit, 35

hernehmen, 19

Herr, 31-32, 34

Herrn, 31, 33, 36
Herz, 29, 32, 34, 40

Herzog, 30

heuristic, 5

hidden, 5

high, 5-6

highest, 9-12, 14, 17-18, 34

highlights, 23

highly, 18

Him, 13

him, 7, 13, 21, 27, 39

himself, 4, 12, 41

Hindernisse, 21

Hindu, 48

Hinsicht, 47

Hirngespinsten, 9

His, 30, 43

his, 2-4, 6, 11-13, 15, 18, 20, 23, 27, 30-36, 38-43, 45-46, 49

Historical, 2-3

historical, 3, 12, 16, 19

historically, 12

History, 44

history, 24, 41

Hohenzollern, 32

holding, 13, 18

Holger, 48

holiest, 17

hominem, 6

honest, 17

honesty, 39-40

hope, 9, 33

horizon, 7

Hours, 6, 18

hours, 31

house, 8,31

How, 48

how, 13, 15, 19-20, 33, 38-39

However, 11, 15

however, 11, 16, 20, 32, 34, 45

Hrsg, 49

hubris, 41

Hugh, 26, 43

Human, 27, 36

human, 4, 6-7, 10-12, 16-17, 20

humans, 13

Humboldt, 40

humbug, 32

Hume, 27-28, 33, 38

Hyperion, 35

hypothesis, 12

höchsten, 11, 14

Hölderlin, 29, 34-35 
I

Ich, 33, 42

idea, 10-11, 20, 37, 39

ideal, 11

Idealism, 33

idealism, 42

Idealismus, 33

ideality, 45

Idealität, 47

ideas, 27, 40

identify, 9

If, $3,5,23,27$

if, $3,5,7-15,17,19-21,32,45$

ignorance, 8

ignorant, 27

ignore, 23

ihm, 36

Ihr, 17

ihren, 35

ihrer, 36, 47, 49

II, 31-32, 46-47

III, 32

Illinois, 43

ills, 15

im, 1-2, 18, 22, 25, 33, 47

Image, 2

image, 5, 11

imaginary, 20

imagine, 20

Immanuel, 1-2, 5, 21, 25-26, 28-29, 36, 43-44, 46, 49, 51

immediate, 13

immediately, 13, 32

immutability, 19

impact, 13

impeded, 21

Imperativ, 47

imperative, 45

implore, 32

importance, 18

important, 10, 24

imposed, 15

impossibility, 10, 14, 20

impression, 15, 32

improve, 3

In, $5,8,12-13,20,23,25,27,35,38,40-41,44-45,47$

in, $1-28,30-49,51$

inadequacy, 11,18

incidentally, 7

inclination, 33, 35 include, 20

including, 48

inconsistence, 10

Indeed, 3, 27, 38-39

indeed, 6, 8, 12, 19, 31, 41

indemonstrable, 45

independence, 16

independent, 11

independently, 17

index, 2

Indirectly, 40

indispensable, 36

individual, 21

indubitable, 45

inevitable, 6, 15, 20

inevitably, 7, 45

inexplicable, 45

inferior, 13

infinity, 14

influence, 40

ingenious, 6, 18

inhibit, 19

initial, 32

initially, 16

inner, 16, 33

innerhalb, 34

innocence, 17

Inquiries, 36

inscription, 34

inseparable, 11

insight, 10-14, 18-19, 27

insights, 11

insisted, 11

insofar, 20

inspiration, 12-13, 16

inspired, 32

installment, 33

instead, 9, 11, 15

Institute, 42

insufficient, 12

insurrection, 45

intellect, 5

intellectual, 4, 27, 39-40, 42

intellectuals, 42

intelligence, 10-11

intelligent, 10

intended, 45

intending, 8

intense, 3

intention, 6, 13, 31

interest, 11

interested, 4

interesting, 45 
interim, 34

internal, 13

interpretation, 3, 23-24

interweaving, 27

into, 1-3, 5, 10, 16, 20, 23, 26-27, 31, 35-36, 39, 42

introduction, 26

intuition, 5, 7-8, 13-14, 45

intuitions, 5, 45

invalidity, 16

invention, 27

investigate, 9

investigating, 14, 27

Investigations, 27

investigations, 20, 41

involved, 32, 41

irresistible, 36

Is, 30

is, $2-21,23-27,30-32,34-36,38-42,45,48,51$

isms, 27

isolation, 38

issues, 39, 42

ist, $10,21,24,40,46$

It, 9, 11, 16, 19, 27, 32, 42, 45

it, $1-2,4-21,23,25,27,31-34,36,38-39,41,45,48$

items, 8

its, 6, 9-11, 15-16, 19-20, 27, 35-36, 39, 45

itself, $8,11,14,16,18,20,32$

$\mathbf{J}$

Jacob, 40-41

Jacobi, 4, 6, 17, 28-38, 41-42

Jacobian, 14, 17, 32

Jacobischen, 32-33

Jakob, 29, 33

Jan, 49

January, 31-32, 34-36

jeden, 31

Jena, 35-36, 41-42

jene, 21

Jerusalem, 30

jest, 8

Jesu, 30

Jesus, 30

Jo, 49

Joan, 27

Johann, 3, 27-30, 32, 34

John, 29, 38-39, 43
Joseph, 30, 49

Josua, 29

Journal, 35

journal, 26

joys, 35

jr, 49

Juanita, 49

judge, $8,10,13,18$

judging, 8

Judgment, 24, 34, 43-44

judgment, 8, 11-12, 27

judgments, 8

Julius, 49

July, 30-31, 35-36

June, 32

Juni, 24

Just, 13, 20

just, 4, 7, 10, 12-14, 16, 20, 27, 31, 33, 48

justice, 33

justified, 19

justify, 16

Jünger, 30 kai, 30, 34

Kaiden, 49

Kaliningrad, 31

Kamlesh, 49

Kant, 1-6, 8, 10-11, 13-14, 17-36, 38-46, 48-49, 51

Kantian, 24, 28, 33, 39, 42, 48

Kantische, 33

Kants, 25, 43, 46

Karl, 29, 33, 35, 40

keep, 13-14

Keyword, 2

Khambholaj, 49

Kierkegaard, 40

kind, 9, 12-13, 27, 39

King, 32

Kingdom, 31

Kiran, 49

Kleinod, 15

knew, 20

know, 6-9, 12-15, 23, 31, 37, 39

Knowledge, 36

knowledge, 6-8, 11-14, 19-21, 42

known, 6, 8, 27 
Kritik, 30, 33-34, 42

kritisch, 32

kritische, 40

Kuhn, 49

Kumar, 48

Kurze, 34

Königsberg, 1, 17, 21, 30

könne, 46

können, 31

künftigen, 31

$\mathbf{L}$

la, 34

label, 27

Labeled, 17

labels, 27

lack, 8, 10, 12, 19

lacked, 11

lacking, 18

language, 16, 23, 39

langwierig, 21

Large, 49

larger, 39

Last, 33

last, 5-6, 11-12, 15-17, 24-25

lasting, 18

late, 34

Later, 31,42

later, 23, 40, 45

Latin, 6-7, 23, 34

latter, 6, 11, 14, 40

Laurie, 49

Lavater, 31

law, 11, 15, 19

lawful, 17

lawgiver, 34

lawless, 15

lawlessness, 15

laws, 9-10, 15-17, 19

lay, 10, 18

LB1, 45

lead, 10, 32, 40

leaded, 16

leads, 4, 20

learn, 9, 23

Learned, 31

learning, 23-24 least, 9-10, 13, 16, 18, 20, 28, 32

Lecture, 40

lectured, 39

Lectures, 44

lectures, 31, 39

lecturing, 35

left, 5, 7-9

legacy, 41

legal, 16

legislative, 16

Lehre, 31, 47

Leibniz, 4, 28-29

Leibnizians, 4

Leipzig, 17

lengthy, 3, 21, 34, 43

Leonhard, 29, 33

less, 9

lesser, 27

Lessing, 2, 6, 28-31, 34, 41, 43-44, 49

Lessings, 31

Let, 24

let, 18,24

Letter, 31, 33, 35-36

letter, 23, 31-35, 39-40

Letters, $17,31,33$

letters, 4, 6, 12, 33, 39, 45

Lewis, 48

librarian, 30

Library, 31

library, 30

License, 2, 22

lich, 47

Liebmann, 48

lies, 5

Life, 43

life, 35,45

lifespan, 11

lifetime, 33

light, 4

LII, 31

like, 3, 9, 16, 23, 39, 41, 48

liked, 11

likes, 16

likewise, 39

limited, 10, 38

limiting, 20

Limits, 39

limits, 8

line, 6,11

lines, 45-46

link, 9, 32

linked, 4, 41

linking, 4 
links, 44

lips, 34

literacy, 20

literally, 41

Literatur, 30

lived, 35, 38

lively, 19

lives, 35

living, 30

loathsome, 32

located, 30

location, 8

Locke, 29, 38

Logic, 44

logic, 5

logical, 8, 13, 38

logomachies, 24

London, 42

long, 12, 15-16, 20, 23, 48

longer, 8, 11, 31, 41

look, 3, 11, 13, 18, 40

looking, 3, 20

looks, 14

Lord, 36

Loren, 49

lose, 17

loses, 35

lost, 15

lot, 27

lots, 39

Louise, 49

love, 14

Lower, 30

Ltd, 43

Ludwig, 29, 33

lumbering, 16

lunch, 48

Luther, 23

lying, 36

Lüge, 36

M

made, 5-6, 32-33, 36, 39

madness, 14

Mai, 46

mails, 48

Maimon, 29, 34
Main, 2, 29

main, 3-4, 34

mainly, 6

maintains, 41

major, 23, 41

make, 3, 8-9, 20-21, 23, 27, 32, 38, 41-42

makes, 8, 13, 17-18, 23, 30

making, 5, 39

Maliha, 49

Man, 36

man, 12-13, 32-33, 35, 45

mankind, 36

Mann, 47

manuscript, 31

Many, 30, 39

many, 5, 9, 11-12, 23-24, 39-40, 48

March, 1, 37

Marcus, 29, 32, 34, 40

marginalia, 30

Marguerita, 49

marketing, 33, 38, 42

Markus, 29

Martin, 23

Marx, 40

Mass, 42

Masse, 47

master, 41

materials, 20

mathematical, 16

mathematically, 8

mathematicians, 19

matter, $8,13,33$

matters, 6, 10, 14-16, 19

matura, 23

maxim, 5-8, 11, 15-16, 20-21

May, 32, 34, 45

may, 5, 7, 9, 12-13, 17, 33

maybe, 36

me, 8, 12-13, 24, 34

Mean, 1-2

mean, 15, 25, 30, 32-33

meaning, 5, 7, 9

means, 6, 9, 11, 15-16, 18-19, 30, 45

meant, 5

measure, 46

Mechanism, 47

mechanism, 45

media, 38

medium, 8

meets, 30

Melchior, 29-30

members, 48-49

Men, 14 
men, 33

Mendelsshohn, 31-32

Mendelsshohnian, 17, 32

Mendelssohn, 4, 6, 11-12, 17-18, 28-31, 33, 38, 41

Mendelssohnian, 14

Mendelssohnschen, 32-33

Menschen, 36

Menschenvernunft, 6, 11

menschlichen, 36

mental, 14

mentality, 16

mention, 18, 34

mentioned, 15, 32

Mere, 34

mere, 6, 8-9, 11, 27

merely, 6-8, 10-12, 45

merit, 11

message, 13

messages, 39

Metaphysic, 31

Metaphysical, 32

metaphysical, 4

Metaphysics, 31, 35, 44, 48

metaphysics, 4, 28, 38-41, 45

Metaphysik, 31, 35, 46

Metaphysische, 32

method, 5, 19, 39

methodology, 38

mich, 24

middle, 4, 35

might, 5, 32, 34, 39

Mikhail, 40

mind, $8,11,16,19,39-41$

minds, 21

mine, 23, 48

Minerva, 32

miracle, 7

misfortune, 15

misunderstood, 12, 32

mixed, 39

mixes, 16, 38

mixture, 31

modern, 44

Monatschrift, 25, 49

Monatsschrift, 25, 32-34, 49

monstrous, 31

month, 39

Monument, 36

moral, 10-11, 16, 19, 36

moralisch, 46

morality, 10-11, 38, 40, 45

Moralität, 47

morally, 13, 45
Morals, 27, 35

morals, 40

more, 3, 6, 8, 10-12, 15-16, 20, 23, 27, 31, 39-40, 42, 48

Moreover, 42

Morgenstunden, 31, 33

Morning, 6, 18, 31

Moses, 17, 29, 31

most, 17-18, 23, 27, 32, 34-35, 39-40

motion, 6

Motto, 36

motto, 34, 48

mountain, 35

move, 40

movement, 3, 7, 11, 28

movements, 28

moves, 31

Mr, 36

much, 6, 8-9, 11, 13, 15-16, 20-21, 38-39, 41

muss, 48

must, 5, 7, 10-16, 18-20, 27, 32, 36, 41, 48

mußte, 42

My, 23, 48-49

my, 3, 7-8, 12-13, 23, 26, 33-35, 40, 48

myself, 7-8, 33

mysticism, 28

Mühsal, 24

$\mathbf{N}$

nach, 18, 47

Nachfolger, 49

Nachlaß, 45

nakedness, 6

name, 6, 12, 32, 48

named, 41

namely, 3, 6-7, 9-10, 17-18

Nathan, 30

national, 17

native, 23

Natu, 49

Natur, 47

Natural, 32, 44

natural, 11, 15

naturally, $7,12,15$

Nature, 35

nature, 7, 9-10, 12-13, 16, 39-40, 45

Naturwissenschaften, 32

NC, 2, 22 
nd, 23, 26, 30, 33-34

necessary, 6, 8-9, 12-13, 18, 20, 31

necessity, 6, 18

neck, 17

nee, 49

need, 7, 9-13, 16, 18-19

Needless, 41

needs, 10

negations, 18

negative, 20

neither, 13, 19

Neo, 20

Neue, 49

never, 12-14, 20, 24, 32, 45

Nevertheless, 27, 36

nevertheless, 9, 13, 16, 18

New, 26, 42

new, 20, 38

newspaper, 32

Next, 32

next, 7, 23

nice, 23

nicht, 47

nie, 46

Niethammer, 29

Nietzsche, 24

night, 7, 9

nighttime, 8

nihilism, 4, 28, 36

Nikolaus, 27

nimble, 16

Nisbet, 26, 43

No, 40

no, 4, 6-10, 12-14, 16, 18-20, 23, 28, 30-31, 33-34, 36-37, 41

noblest, 36

nobody, 19

noch, 17,40

Non, 2, 22

non, 6

nonanthropocentrism, 28

None, 34

none, $8,13,34$

nonsense, 15,19

noon, 7

noonday, 35

nor, 13, 19

Normal, 25

north, 7

northern, 38

Northwest, 43

not, 3-21, 23-24, 31-32, 34, 37-41, 45, 48

Notation, 45
Note, 2, 30, 39, 42, 45

note, $12-13,17,19,45$

notebooks, 24

noted, 34

Notes, 2, 25, 44-45

notes, 2, 26, 31, 45-46

nothing, 6, 8-10, 12-13, 15-16, 18, 20-21, 32

notice, 7

noticeable, 7

notified, 15

notion, 6,10

November, 31, 33

Now, 10, 13, 19, 31, 34, 45

now, 5, 7-9, 12-13, 16-18, 20, 34, 36

nowhere, 11

number, 25

nun, 46

nur, 47

$\mathbf{O}$

obedient, 32

object, 8-9, 14

Objecte, 47

objective, 8-12, 16, 18, 21

objectively, 12, 18

objectives, 11

objects, 6-9, 13-14, 19, 45

objektiven, 18

observation, 11

obstacles, 21

obviously, 8

occasion, 18

Ochsenmarkte, 30

October, 1, 22, 25, 31, 33, 40, 49

oder, $31,33,35$

Of, 15, 20, 23, 43

of, 2-21, 23-46, 48-49, 51

off, 38,41

offen, 40

Offenbarung, 6, 13, 36

official, 38

often, 39

Oh, 36

Oker, 30

old, 11, 23, 38, 41, 49

older, 20

omitted, 5, 45 
On, 6, 12, 17, 30-31, 34-36, 38

on, $2-3,6-14,16-17,23-24,27,30,32-34,36,38-42$, $44-45,48$

once, 16,27

One, $8,30,34$

one, $4,8,10-14,16,18,20-21,27,32,35,41$

ones, 20

Oneself, 1-2, 5

oneself, 18, 25, 32-33

Online, 2, 43, 49

online, 46

Only, 32

only, 6-15, 17-21, 32, 34, 38-41

onto, 38

ontology, 39

Open, 35

open, 24, 27, 39-40

opened, 14

opening, 24

openings, 14

openly, 36

openness, 40

opinion, 6, 12

opinions, 31, 33, 36

opponents, 6

opposed, 15

opposite, $7,12,15,23$

opposition, 6

oppressive, 35

option, 41

Opus, 44

or, 2-4, 6-16, 19-21, 23-25, 28-36, 38, 40-42

order, $8,10-11,42$

ordered, 13

Orient, 1-2, 5, 18

orient, 7-9, 11, 25, 32-33, 38

Orientation, 2, 34, 38

orientation, 4, 6-7, 33, 42

oriented, 11

orientieren, 1-2, 18, 25, 33

Orienting, 7

orienting, 7

origin, 24

original, 31, 51

originally, 18

other, 5-18, 23, 27, 30, 33, 36, 42

others, 15,42

otherwise, 5-10, 17

Otto, 48

Our, 35

our, 4-5, 8-11, 18-20, 31-33, 38, 48

ourselves, 8, 38

out, 10, 13-15, 27, 31, 33, 41, 45 outlines, 39

outlook, 38

outside, 16, 38

outstanding, 48

outward, 7

over, $7,15,23,40$

Overall, 2, 45

overall, 34, 40-42, 45, 48

overcoat, 32

overcome, 42

overly, 23

overnight, 7

own, 6-9, 11, 15-17, 19-20, 27, 30-31, 38-41

Oxford, 43

Page, 22

page, 2-4, 6, 21-22, 25-26, 44-45, 49, 51

pages, 2-3, 6, 25-26, 31, 35, 49

pain, 33,36

pained, 32

pan, 30, 34

Pantheism, 2-4, 27-30, 32, 34, 38, 41-42, 44

pantheism, 4, 23, 30, 41-42

Pantheismusstreit, 2, 27, 29

paragraphs, 23

Part, 38

part, 31, 38-39, 43

partial, 41

particular, 23, 49

particularly, 49

particulars, 5, 9, 11-12

partly, 21

parts, 17, 39-41

passage, 39

passed, 11

Pastor, 49

Patel, 49

path, 4, 18, 39-40

paths, 40

pauca, 23

Paul, 44, 46

Peace, 34

peak, 35

peek, 12

Peer, 49

pendant, 18 
people, 14-16, 33

perception, 5

perform, 18

performing, 13

Perhaps, 4

perhaps, 4-5, 39

period, $3,27,45$

periods, 45

permit, 31

pernicious, 6

Perpetual, 34

person, 6, 27, 32

personal, 4, 28, 30, 48

perspective, 33

persuasion, 16

Peter, 49

phenomena, 14

phenomenology, 39

phenomenon, 10, 13

philologist, 23

Philology, 24

philosopher, 4, 27, 32

Philosophers, 2

philosophers, 4, 27, 29-30, 37, 40

Philosophical, 2, 27, 30, 34, 36, 45

philosophical, 3-4, 18, 23-24, 27-28, 38-42, 48

philosophically, 4, 37

Philosophie, 32-33

Philosophische, 36

philosophischer, 34

Philosophisches, 35

Philosophy, 17, 32-34, 44, 48

philosophy, 3-5, 23-24, 27, 30-34, 36, 38-42

phrases, 45

pictorial, 5

pieces, 8

pinnacle, 35

place, $4,8,10-12,15,30,35,38,41,44$

placed, 5,13

plan, 32, 39-40

planned, 39

planning, 39

plans, 39

Platonists, 20

Platz, 42

play, 9, 16, 30

pleased, 35,40

pleases, 14

point, 13, 30, 32, 36-37, 40

pointless, 12

points, 7, 27

pole, 7

police, 36
Political, 26

popular, 32, 38, 41

pose, 15

Position, 2, 45

position, 4,7

positions, 4,27

possibility, 9, 14, 18, 20

possible, 5, 9-10, 13, 18-19, 32, 41

possibly, 14

posthumously, 31

Postulat, 13

postulate, 13

Postumum, 44

Potentially, 4

pounding, 33

Power, 34, 44

power, 6,16

Practical, 23, 33, 44

practical, 10, 13, 34, 36, 38-39, 45

practische, 47

practischen, 33

practischer, 46

praised, 6

precaution, 9

precede, 14

precise, 41

Precisely, 20

precisely, 19

predicament, 16

predicted, 18

Preface, 2-3, 34, 42

prefer, 31

prefigure, 13

prescribed, 15

present, 12, 40

Presentation, 34

presented, 27

preservation, 21

Press, 26, 42-43

presume, 9

presumption, 20

presumptuous, 16

presuppose, 12, 18

presupposes, 10

prevent, 11,19

previous, 7,23

previously, 8, 32

primarily, 10

primary, 9,19

principle, 6, 11, 16, 18, 20, 33

Principles, 27

principles, 7, 11, 14, 18-19, 31, 34, 39-40

Prinzessinstraße, 31 
Prinzip, 18

Prinzipien, 18

priori, 7, 20

Private, 36

private, 40

Privatschreiben, 36

privilege, 17

probably, 5, 8, 13-15, 21

problematic, 3

proceed, 17

proceeded, 20

process, 7, 15, 32

processing, 7

professional, 23

Professor, 33, 48

professor, 33

profound, 31

progress, 40

prohibit, 21

Project, 34

project, 48

projects, 23

Prolegomena, 31, 48

promotion, 4

promptings, 16

proof, 18-20

propel, 15

propensity, 36

proper, 7-8

property, 6

proportion, 10

proposition, 6

propositions, 21

prove, 10, 13-14, 36

proved, 16

proven, 16

proves, 19, 45

provided, 4, 10

provoked, 32

Prussia, 1, 31-32, 38, 49

Prüfung, 33

Pub, 43

Public, 2, 22, 35

public, 32, 40-42

publication, 51

publicly, 15, 34

Publikum, 35

publish, 32

Published, 22, 30, 35

published, 30-31, 33

publisher, 31

publishes, 48

Pulaski, 48 pull, 5, 17

punctuation, 23

Pure, 4, 19-20, 28, 30-31, 33, 38-40, 42, 44-45

pure, 5-6, 8-10, 12-13, 19-20, 40, 42, 45

Purpose, 2, 38

purpose, 3, 7, 9, 13, 18, 42, 48

purposes, 36

pushed, 41

put, $7,10,18,20$

quality, 13

Quarrel, 2, 27, 29-30

quarrel, 2, 30

quarreling, 13

Question, 3

question, 3, 12, 26, 38, 48

questioned, 36

questioner, 48

questions, 24, 34, 48

quite, 9, 12, 19, 21

quoted, 10

quotes, 36

$\mathbf{R}$

race, 17

Rafael, 49

Rai, 48

raises, 16

ramifying, 39

random, 5

Ranked, 2, 29

rather, $6,9,15,20,24,38,40,45$

ratio, 9,38

Rational, 26, 44

rational, 12-14, 16-17, 20, 28, 38, 41

Rationalism, 28, 38

rationalism, 3, 38, 42, 44

rationality, 12, 14

Raume, 47

Rausch, 24

raving, 9, 32 
rd, 24

re, $3,23,39-40,42$

reached, 36

read, 23, 33, 35, 41

reader, 23

readers, 23-24

reading, 23

real, 5-6, 8-9, 18

Realism, 33

Realismus, 33

reality, 11, 14, 18, 27, 45

Realität, 47

realization, 18

realizing, 38

really, $4,10,19,30$

realm, 34

Reason, 4, 19-20, 23, 28, 30-31, 33-34, 38-40, 42, 44-45

reason, 4-21, 36, 38, 40, 42, 45

reasonably, 12

reasons, 4, 8-10, 12, 16, 19, 21

Reavis, 49

recent, 48

recently, 48

reception, 38

recklessly, 41

recognize, 14, 31

recognizing, 16

reconstruction, 36

recorded, 30

rectified, 10

reden, 35

redenden, 36

reflection, 21

refutation, 32

refute, 21

regard, 8-9, 39

Regarding, 36, 41

regardless, 7

region, 7,38

regulation, 10

regulations, 17

Reimarus, 29-30, 43

reine, $6,12,47$

reinen, 20, 30, 33, 42

Reinhold, 29, 33, 35-36

Reinigung, 6

Reiss, 26

reject, 32

rejected, 38

Related, 2, 43

related, 2, 42

relationship, 39

Religion, 26, 34-35, 44 religion, 15,35

rely, 10

remain, 12, 36

remaining, 48

remains, 5, 10-11, 15, 18, 20, 24, 40

remark, 30

remarkable, 36

Remarks, 2, 33

remarks, 23, 30, 36

remedy, 19

Remember, 3, 23

render, 27

René, 29

report, 12

reports, 12,35

reprehensible, 14

represent, 7-8

representation, 13

representations, 5

represents, 14

reputation, 6, 41

request, 20

requested, 33, 35

required, 8

requirement, $8,12-13,18$

requires, $10,13,19,41$

requiring, 7

requisite, 41

requisition, 35

rescript, 35

research, 44

reserved, 2, 22

resist, 15

Resources, 2, 43

respect, $6,19,33,45$

respond, 3

rest, 17,35

restrict, 8

restriction, 15-16

restrictions, 15

rests, 36

result, 15

Resultate, 32-33

Results, 17, 32

results, $6,12,33$

retained, 7

retirement, 16

retires, 35

return, $7,35,42,48$

returning, 48

reveal, 9

Revelation, 36

revelation, 4, 6, 13, 28, 38 
reverence, 34

review, 31

reviewer, 41

Revolution, 42

rewritten, 3

rewrote, 33

rich, 5, 20

Richard, 48

Richtung, 47

right, 7-9, 14, 24, 27

righteous, 6

rights, 2, 19, 22

ripe, 23

rise, 7,14

risk, 15

Rita, 49

River, 30

road, 11

Rockmore, 43

Romanticism, 42

Rome, 12

room, 8, 38, 42

roommate, 34

root, 20

Ruhestand, 16

rule, 5,21

runs, 9

Russian, 31

Ruth, 49

Rücksicht, 46

$\mathbf{S}$

Sachen, 31

sacred, 35

safe, 8

sagt, 47

said, 15, 24, 30

sake, 11, 18, 20

Salomon, 29, 34

salvage, 41

same, 6-12, 14, 16-21, 26, 36, 45

sammt, 47

Samuel, 29, 35, 43

sane, 16

satisfactory, 10, 12

satisfied, 8

satisfy, 36
Satz, 19

saw, 4

Saxe, 35

Saxon, 35

Saxony, 30, 35

say, 12, 15, 18, 20, 34, 41

says, 34, 36, 40-41, 45

scale, 10

scan, 25, 49

Schelling, 4, 27, 30, 34-37, 40

schen, 33

Schiller, 3

schlechterdings, 47

Schlegel, 29

Schleiermacher, 29, 34-35

scholar, 20

scholars, 19

scholastic, 19, 23

school, 48

schools, 40

Schrift, 36

schuldlosen, 17

Schulze, 29

schwärmen, 9

Schwärmerei, 16, 19, 21, 28

Science, 31-32, 44, 48

science, 11, 33-34

scope, 5, 20

Scotland, 39

Scott, 49

sea, 35

Second, 15, 30, 40

second, 24, 39, 42

secondly, 10

secret, 6

Section, 29-30

sections, 39

secure, 9

secured, 36

sed, 23

See, 26, 31

see, 3-4, 6-8, 10, 14-15, 21, 26, 38-41

seems, 12-14, 16-17

seen, 39-41

sees, 7,18

sehr, 21

seiner, 17, 30

Seite, 22

Selected, 2, 42

selected, 16

self, 7, 20-21, 34-35

semester, 35

Sendschreiben, 35 
Sense, 39

sense, 3-6, 12, 15, 23, 28, 38, 41

senses, 5,9

sensibility, 20, 41, 45

sensible, 10, 45

sensualize, 9

sensuous, 5, 14, 40

sent, 34

sentence, 17, 19, 23

sentences, 23

separated, 20

September, 23, 31, 33, 36

Series, 44

series, 44

serious, 32

servant, 32

serve, 6,13

serving, 34

set, $8,14,16,18,20,39$

settle, 6

Several, 45

severity, 19

shackles, 16

shadow, 34

shall, 32, 34, 40

shape, 7

Shobha, 49

Short, 2-3, 36

short, 41

shorten, 31

Should, 4

should, 4, 6-8, 14, 19-20, 41

show, 6-7, 33, 41

shows, 20

Sich, 18, 22

sich, 1-2, 17-18, 21, 25, 33, 47

sicherlich, 17

side, 3,10

sides, 7-8

sie, 17,47

Sigismund, 29

Signed, 32

signs, 27

silence, 34

similar, 8

simple, 6, 27

simply, 4

Since, 18, 41

since, 8, 10-11, 19-20, 41

single, 8, 20, 48

Sinnlichen, 46

Sinnlichkeit, 20, 47

Sitten, 35 size, 14

Skepticism, 28, 38

skepticism, 3, 20

sky, 7

slightest, 7

slow, 16

slumber, 32

small, 10

snatches, 15

So, 7-9, 14-15, 18

so, 5-14, 16-21, 30, 40-41, 44, 47

Society, 32

Sohn, 31

Some, 23, 26, 33

some, 3, 5, 9, 12, 14, 21, 23, 27-28, 33, 35-36, 38-39, 41

someone, 8

something, 8, 10-12, 18, 20-21, 32

sometimes, 6

sondern, 47

sonst, 17

soon, $8,14,16,21,27$

sophistical, 7

sort, 45

sorts, 14

sound, 12-13

source, 4, 12, 38

sources, 14

south, 7

space, 7-9, 45

spared, 27

speak, 14-15, 24

speaker, 23

speaking, 24, 36, 38-39

speaks, 14, 20

special, 38

specific, 7

specify, 10

speculation, 6, 11, 14

speculative, 6, 11, 13-14, 16

Speeches, 35

spells, 16

spend, 18

Spinoza, 4, 14, 17, 28-32, 34-36, 42

Spinozism, 4, 19-20, 33-34

Spinozismus, 34

Spinozist, 33-34

Spinozistic, 34

Spinozistischen, 34

Spinozists, 4

spirit, 41, 45

spirits, 15

spiritual, 9

splendid, 27 
spoken, 33

springs, 19

sprint, 24

spurious, 4

st, 28, 43

stake, 41

Stambaugh, 27

standards, 6

standpoint, 41

stands, 14

star, 7

staring, 48

starry, 7

Start, 5

start, 8

Started, 30

started, 39-40

starting, 30, 40, 44

Starts, 2

starts, 2, 30, 35

state, 11,15

statement, 12, 32, 36

statements, 40

status, 41

stay, 8

steadfast, 6

stems, 18

steps, 19

still, 5, 8-9, 11-12, 15-16, 18-19, 23, 38, 42

stings, 30

stirred, 34

Stone, 32

stop, 19, 24

stopped, 35

store, 36

Storm, 3, 28

straight, 18, 20

streets, 8

strength, 14, 19, 31

stress, 3, 28

Strictly, 38-39

stripped, 16

strives, 16

strong, 39, 42

strongly, 3, 23

student, 28

students, 40

Studies, 42

study, 31

stupid, 37

Sturm, 3, 28

style, 23

su, 47 subject, 7, 10-11, 19-20

subjected, 14-15

subjective, 7-12, 18, 45

subjectively, 12

subjects, 21

subjektiven, 18

subjugation, 15

submission, 16

submits, 17

succeeded, 19

successful, 36

Such, 6

such, 6, 9-11, 13-15, 27-28, 33-34, 41

sufficiency, 41

sufficient, 10, 12

suggest, 3, 23, 35

suitable, 9

Sulzer, 27

summary, 3

sun, 7, 20

supersensible, 6-7, 9, 13, 19, 39, 45

superstition, 14, 16, 21

support, 20

supporters, 42

supporting, 32

supposed, 14

sure, 20, 41

suspicion, 33-34

sweep, 16

switch, 11

symbol, 34

Symbolum, 34

System, 34

system, 18, 21, 27, 35-36, 39-40

Systems, 28, 34

Sätzes, 11

Søren, 40

\section{T}

Table, 2

table, 4

tablet, 20

Tafel, 20

Tagen, 24

take, 11-12, 19-20, 41

taken, 12, 15, 24, 40-41

takes, 7, 30 
talent, 14, 33

talk, 10

taste, 39

Taylor, 35

teach, 23

teacher, 33

teaching, 39, 48

teenage, 11

Teile, 17

Teilen, 35

teils, 21

tell, 32

telling, 41

term, 9-10, 14, 35

terms, 8-9, 12, 14, 19

territory, 6

test, 21

testament, 12

testimonials, 16

Tetens, 27

Text, 2, 5, 46, 49

text, 2, 17, 21, 23-25, 46, 49

texts, 23

th, 30

than, $3,6,8,11-12,15,18,20,23,27,30,48$

That, 8

that, 3-8, 10-16, 18-21, 23-24, 27, 30-32, 34-39, 41, 45, 48

The, 3-4, 7, 9-16, 19-20, 23, 30-32, 34-36, 39-45

the, 2-21, 23-45, 48-49, 51

their, 6-17, 19-21, 31, 36, 40, 45

Theism, 28

theism, 3

them, 5-7, 9, 15-18, 23, 40

themselves, 7-9, 11, 15, 20, 45

then, 5, 8-10, 14, 16, 20, 32, 39-40, 45

theo, 38

theological, 3-4, 34, 38, 42, 44

Theology, 26, 44

theology, 4, 6, 27, 30, 33, 39

Theoretical, 44

theoretical, 10, 12-13, 34, 36, 39, 45

theoretische, 46

theoretischer, 46

There, 9,30

there, $3,8-9,12,19-20,39-40$

thereby, 7, 15

Therefore, 12, 16, 18-19, 40, 48

therefore, 4, 7, 10, 12, 14, 18, 20, 23, 33, 40-41

These, 4, 27, 31, 33

these, $4,7,16,23,25,27-28,39,44-45,49$

They, 18

they, $5,8-11,13,15-18,20,23,27,36-37,39-40$ thick, 9

thing, 18

things, $10,18,20,36$

think, 9, 13-16, 20, 24, 27, 41

thinker, 13

thinkers, 3

Thinking, 1-2, 5

thinking, 4-6, 9, 11, 15-16, 18, 20, 23-25, 28, 32-33, $38-40$

Third, 15,30

This, 3, 7-8, 12, 21, 23, 30-32, 34, 39, 45

this, 3-21, 23-27, 30-41, 44-45, 48, 51

Thomas, 29

thoroughly, 19

those, 9, 16, 20-21, 33, 36

Though, 31

though, 6-7, 12, 38, 40

Thought, 43

thought, 5-6, 8, 11, 15-17, 19-20, 27, 33, 39, 45, 48

thoughts, 15, 20, 35

thread, 16

three, 3

throne, 16

through, 6-7, 9-10, 15-16, 21, 40, 45

throughout, 11

throw, 32

thunder, 35

Thus, 4, 38, 41-42

thus, 16-17

time, 4, 7, 10-11, 16, 19-20, 30-31, 34, 42, 45-46, 48-49

timeline, 45

times, 39

title, 25, 36, 39, 41

Titles, 44

To, $15,25,31,33,35,40,48$

to, $1-21,23-25,27,30-42,44-46,48$

together, 12, 45

tolerate, 14,31

tongues, 16

too, $4,23,31,36$

took, 31

top, $15-16$

topics, 44

total, 9,42

totality, 9

totally, 32

touch, 8

touching, 36

touchstone, 11-12, 17, 20

Toward, 34

toward, 40, 45

towards, 35

town, 30 
trace, 33

tracking, 13

tracks, 11

trades, 17

tradition, 6, 39

traditions, 16

training, 21

transcendent, 45

Transcendental, 34

transcendental, 40, 42, 45

Transcendentalphilosophie, 34

translate, 3

Translated, 26

translated, 2-3, 26

Translation, 1-2, 22, 43, 46

translation, 2-3, 5, 21, 23, 25-27, 48

translations, 2-3, 23

Translator, 2-3, 6-7, 12, 17, 19, 23, 38, 42, 45

translator, 23, 26-27

Translators, 13

translators, 23

transscendent, 46

transscendentalen, 46

travel, 35,38

treasure, 15

trivial, 6

trouble, 27

true, 12-13, 15, 18-19

trusted, 6

truth, $6,12,17,20,38$

try, 23

trying, 24, 32, 41

tthold, 43

turn, 39-40

turns, 14

Two, 24, 39

two, 7-8, 30-31, 39-40

twofold, 10

type, 9

täuschenden, 36

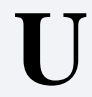

um, 42

umgekehrter, 47

unaccustomed, 16

unambiguously, 14

unbelief, 16 unbezweifelte, 47

und, $3,17,24,28,30,32-33,36,46-47,49$

under, 5-6, 8-9, 12, 15, 20, 48

underpins, 8

understand, 5, 19, 23, 41-42

understandable, 10

understanding, 5, 9, 20, 23, 45

understood, 27, 34, 41

underway, 3

Uneingeschränkten, 10

unerklär, 46

unerweislich, 47

unforgettable, 30

Ungereimtheiten, 10

Unglück, 17

unifying, 11

united, 34

universal, 39

University, 26, 35-36, 39-43, 48

unlimited, 2, 22

unmittelbare, 13

unmolested, 14

unrestricted, 10

unsafe, 13

unsers, 35

unter, 35

untersucht, 32

Untersuchungen, 36

until, 4, 9, 32

unusual, 31

unvermeidlicherweise, 47

Unveränderlichkeit, 19

Unwesen, 9

unworthy, 17

unwürdig, 17

Unzulänglichkeit, 18

up, 4, 31, 34, 36, 39, 45

upon, 16, 27, 33

upper, 20

upset, 40

upsetting, 14

Urge, 3, 28

URL, 26

Urteilskraft, 34

us, 7, 9-10, 13-15, 48

usage, 36

use, $6,8-18,20-21,23,45$

Used, 35

used, 27-28, 34

useful, 5

useless, 18

uses, 21, 36

utter, 6 
utterly, 8

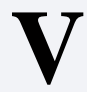

valid, 12, 16

value, 11

Vandana, 49

various, 33

vast, 9

veneration, 34

verbieten, 21

Verden, 49

Verfasser, 33

vergönnet, 11

Vermeynten, 47

vermittelst, 46

Vermögen, 47

vernichtet, 47

Vernunft, 6, 8, 13, 18, 30, 33-34, 42, 47

Vernunftglaube, 14, 28

Vernunftglauben, 19

Vernunftglaubens, 12, 14

Vernunftgründe, 17

Vernunfthypothese, 12

Vernunftstreifereien, 13

Vernunftvermögens, 20

version, 2, 22, 28, 31, 38, 41-42, 44

versions, 3

Verstandesbegriffe, 20

Versuch, 34

Very, 36

very, 4, 7, 10, 14, 19, 21, 24, 30, 45

Verzichttuung, 16

Verächtern, 35

via, 48

viel, 21

Viele, 24

view, 6, 10, 13, 27-28, 38, 42

views, 4, 33

VIII, 22, 25

violence, 15

Vocation, 36

voice, 35

vollig, 46

Volume, 25, 35

volume, 25

Volumes, 25, 31

volumes, 43
Volunteer, 17, 32

Von, 30, 36

von, 29, 31-33, 36, 40, 46-47

Vorarbeit, 31

vorgegangene, 7

Vorlesungen, 31

Vorschrift, 10

Vorstellung, 5

Voss, 31

vs, 28

vulgar, 6

völlig, 47

\section{W}

wahrer, 15

walk, 48

walls, 8

want, 4, 6, 9-10, 15, 17, 19, 24

wanted, 4-5, 38-39, 41-42

wants, 8, 14, 39, 41

warp, 39

Was, 1-2, 22, 25, 33

was, 3-4, 6-11, 13, 18, 23-24, 27-28, 30-34, 37-42, 45, $47-48$

way, 3, 5-6, 11, 13, 15-16, 18, 20, 23, 27, 34, 37-38, 40

We, 5, 14, 24, 36

we, 4-5, 7-10, 12, 14-16, 18, 21, 34, 41, 48

weakened, 32

weaknesses, 18

wealth, 11

web, 26

weft, 39

Weg, 40

wegleugnet, 16

Weimar, 35

Weise, 30

welche, 21

well, 6, 10, 12-14, 16-19, 23, 27, 34, 36, 41, 45

Weltbesten, 17

Weltregierung, 35

went, 48

werden, 46, 48

werdet, 17

Were, 4

were, 3-5, 13, 16, 24, 31, 34, 40, 45

Werke, 25, 43, 46

Wesen, 9, 14, 36 
Wesens, 11, 13-14, 18

west, 7

What, 1-5, 24-26, 30, 32-33, 38

what, 7-9, 13-19, 21, 31, 36, 41, 45

whatever, 13

When, 8

when, 6-8, 10-11, 18, 27, 33, 39-40

Where, 3

where, 6, 8-9, 14-15, 19, 35-36, 48

whereby, 11

whether, 6, 10-14, 16

Which, 4, 20

which, 5-20, 30, 32, 34, 40, 45

while, 19, 35

whipped, 4

White, 48

Who, 6, 24

who, 3, 12, 23-24, 27, 30, 36, 41

whole, 9, 13, 18, 30

wholesomeness, 11

Whom, 4

whom, 33-34

whose, 5, 8-9, 20, 35

why, 21

wide, 14

Wider, 13

Widersprüchen, 9

Widrigenfalls, 17

wife, 49

Wilhelm, 29-30, 49

will, 6-8, 11-15, 17, 19, 21, 28, 31, 33, 36, 41, 48

William, 32, 35

Williams, 48

wing, 19

winter, 30

wird, 31

Wise, 30

wise, 34

Wissen, 36, 42

Wissenschaft, 31

Wissenschaften, 11

Wissenschaftslehre, 36, 41-42

With, 33

with, 2-5, 9, 12-16, 18-19, 21, 24, 26-28, 30-35, 39, 41, 45,48

within, 34

Without, 7, 10, 14

without, 7, 9-11, 14-16, 18, 38

Wizenmann, 17, 29, 32-33

wohl, 17, 46

Wolfenbüttel, 30, 49

Wolfenbütteler, 43

Wolff, 28-29, 38
Wolffian, 27-28

Wolfian, 19

Wood, 26, 44

word, 7, 12, 15-16, 23, 28, 34

wording, 3

words, 20, 27, 34, 41

Wordsworth, 35

Work, 23

work, 23, 31, 39-40

worked, 39

working, 34

Works, 43-44

World, 35

world, 7, 9-10, 12, 14, 17, 38, 41

worldview, 38

worldviews, 4, 42

worry, 23

worship, 31

worth, 48

worthy, 18, 32-33

would, 4-15, 17, 19, 21, 24, 32, 34, 37, 39-40, 45, 48

write, $3,15,19,23,32$

Writer, 30

writes, $23,32,34,48$

writing, 3, 31, 35-36, 39

Writings, 26

writings, 6, 30-31, 39, 43-44

written, 23, 30-31, 39, 45

wrote, $3,23,27,32-33,41-42$

wrung, 18

wäre, 17, 47

wären, 47

Wülbern, 49

würde, 47

würden, 47

würken, 9

$\mathbf{X}$

XXVII, 31 
year, 2, 29-30

yearbook, 34

years, 11, 23, 25, 39, 49

yes, 13, 38

yet, $6,8-9,12,14,16,19-20,34,38$

yoke, 15

Yolanda, 43

You, 8, 14, 33-34

you, 3, 6, 8, 10, 14-17, 19-21, 23, 27, 31-34, 39

Young, 49

young, 21, 33

your, 14-15, 19, 27, 31-34

yourself, 6, 14, 16, 20, 34

\section{$\mathbf{Z}$}

Zaborowski, 48

Zammito, 39, 43

zeal, 6

Zeile, 46

Zeit, 47

Zeitalter, 21

ziehen, 17

zieht, 47

zierete, 16

Zoe, 49

zu, 17, 31, 33, 42, 46

Zugabe, 31

Zum, 34

zum, 17, 42

Zur, 30

zurückgegangen, 48

Zusammenhange, 47

zusammenhängenden, 36

zusamt, 11

zutraute, 11

Zwecke, 30

zweckmäßig, 17

zwei, 35 äußere, 21

\section{E}

ædia, 43

$\ddot{\mathbf{U}}$

Über, 31, 33, 35

über, 17, 31, 33-34, 36

überhaupt, 18

Übermu, 15

Übersinnlichen, 19, 46

übersinnlicher, 6-7, 19

Übersinnliches, 9, 39

übrigen, 17

\section{bÿs}

py $\ddot{y}^{\circ} \pm v, 30,34$

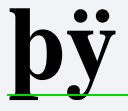

pÿ II, 34

pÿ $\llbracket 1 / 2,30$ 


\section{Index}

\section{p $\ddot{\mathbf{y}}$}

pÿ1/2, 30, 34 